http://kitaibelia.unideb.hu/

ISSN 2064-4507 (Online) • ISSN 1219-9672 (Print)

(C) Department of Botany, University of Debrecen, Hungary

24(2): 117-152.; 2019

DOI: $10.17542 /$ kit.24.117

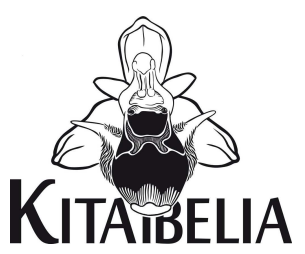

\title{
A Velencei-hegység növényföldrajzi és florisztikai kutatásának eredményei
}

\author{
BAUER Norbert \\ Magyar Természettudományi Múzeum, Növénytár, \\ H-1089, Budapest, Könyves K. krt. 40.; bauer.norbert@nhmus.hu

\section{Results of floristic and phytogeographical research in the Velence Hills (Hungary, Transdanubian Mts)}

\begin{abstract}
A recent floristic mapping of the Velence Hills has clarified the local distribution of many plant species. This study presents records of 219 phytogeographically significant or sporadic/rare taxa (216 species/subspecies and 3 natural hybrids). The local distribution of some species representing typical regional distribution patterns (Alyssum turkestanicum, Artemisia austriaca, Bupleurum pachnospermum, Doronicum hungaricum, Hypericum elegans, Lathyrus sphaericus, Minuartia viscosa, Ornithogalum comosum, Scabiosa canescens, Sedum caespitosum, Sternbergia colchiciflora, Vinca herbacea) are shown on maps. More than fifty taxa previously unknown from the area were recorded during the floristic mapping, including phytogeographically significant ones, such as Bassia laniflora, Brassica elongata, Bupleurum praealtum, Centunculus minimus, Hypericum elegans, Orlaya grandiflora, Phleum bertolonii, Silene dichotoma, Stipa tirsa, Tordylium maximum, Trifolium diffusum, T. ochroleucon and Valeriana dioica. In terms of phytogeography, the Velence Hills can primarily be characterised by the co-existence of continental and sub-Mediterranean elements as well as species of acidophil and strongly basic habitats.
\end{abstract}

Keywords: continental, distribution pattern, flora mapping, granite, loess, plant geography, subMediterranean, Transdanubian Mts

Összefoglalás - A Velencei-hegység flórájának és növényföldrajzi vonásainak pontosabb feltárására irányuló térképező munka eredményeként számos növényfaj regionális elterjedési mintázata tisztázódott. Jelen közleményben 219 növényföldrajzi szempontból fontos, ill. szórványos/ritka taxon (216 faj/alfaj és 3 természetes hibrid) előfordulási adatait mutatom be, és felvázolom a hegység növényföldrajzi jellegzetességeit a korábbi közlemények és az új megfigyelések tükrében. A Velencei-hegység különlegessége, legfontosabb növényföldrajzi vonása egyrészt a markáns kontinentális és szubmediterrán hatások együttes érvényesülése, másrészt az acidofil és az erősen bázikus termőhelyek mozaikosságából fakadó sokszínűség. Néhány, a regionális elterjedési mintázat-típusokat jól reprezentáló faj (Alyssum turkestanicum, Artemisia austriaca, Bupleurum pachnospermum, Doronicum hungaricum, Hypericum elegans, Lathyrus sphaericus, Minuartia viscosa, Ornithogalum comosum, Scabiosa canescens, Sedum caespitosum, Sternbergia colchiciflora, Vinca herbacea) elterjedését térképeken is bemutatom. A térképező munka során több mint ötven, a területről korábban nem ismert taxon is előkerült, köztük biogeográfiai szempontból fontos fajok is, mint pl. Bassia laniflora, Brassica elongata, Bupleurum praealtum, Centunculus minimus, Hypericum elegans, Orlaya grandiflora, Phleum nodosum, Silene dichotoma, Stipa tirsa, Tordylium maximum, Trifolium diffusum, T. ochroleucon, Valeriana dioica.

Kulcsszavak: Dunántúli-középhegység, elterjedési mintázat, flóratérképezés, gránit, kontinentális, lösz, növényföldrajz, szubmediterrán 


\section{Bevezetés és előzmények}

Az alföldi tájból alig kiemelkedő Velencei-hegység flórájának és vegetációjának első adatait Kitaibel Pál gyűjtötte. Több útján $(1799,1806,1808,1816)$ érintette a Velencei-hegységet (vö. Goмвосz 1945, Lókös 2001), „Lovas-Berény”, Pátka, Pákozd, Sukoró, Nadap, „Velencze”, „Meleghegy” lelőhelyekről néhány értékes botanikai (pl. Artemisia austriaca, Astragalus asper, Glaucium corniculatum, Iris pumila, Salvia austriaca, Vinca herbacea), valamint ásványés kőzettani megfigyelést jegyez. Sadler József a Balatonhoz vezető botanikai kutatóútján, 1817. május 24-én érintette a Velencei-tó északi partjának településeit. A Velence, Sukoró, Pákozd útvonalon, a heves csapadék és a felázott talaj miatt botanizálni, gyűjiteni nem tudott, de feljegyezte, hogy a tó partja csak úgy szürkéllett a még fejletlen „Camphorosma ovata” példányoktól (SADLER 1817). Tauscher Gyula MTM Növénytárában őrzött herbáriumában számos 19. századi növénypéldány található a Velencei-hegység területéről, de erről a gyűjteményről Boros (1954) megjegyzi, hogy számos adata bizonytalan; feltételezhető, hogy nem itt gyújtött példányokat is itteni lelőhelynevekkel cédulázott. Egyik legfontosabb adata a Cardaminopsis petraea, Nadap mellől (BAUER et al. 2008). A Velencei-hegység és a Velencei-tó flórájának feltárásában Anton Kerner igen jelentős szerepet játszott. Dolgozataiból egyértelmű, hogy nemcsak Kitaibel és Tauscher eredményeire (herbáriumaira) támaszkodott, de saját terepi feljegyzései, gyűjtései is vannak a térségből; számos növényföldrajzilag kiemelkedő jelentőségú faj első közlése cikksorozatában (KERNER 1867-1879) jelent meg: Ajuga laxmanii, Doronicum hungaricum, Helleborus dumetorum, Salicornia europaea, Sempervivum „tectorum” stb. Nagyobb számú Velencei-hegységre vonatkozó adatot közölt Fanta Adolf, de Székesfehérvár környékének flóráját bemutató cikkében a bizonyosan velenceihegységi megfigyelések csak azok, amelyeket „gránittalajról” megjegyzéssel említett (FANTA 1902). Degen Árpád 1894 és 1931 között néhány alkalommal gyűjtött a Velencei-hegységben, számos fontos fajt (Cleistogenes serotina, Corydalis pumila, Lathyrus sphaericus, Pulsatilla grandis) elsőként dokumentált a területről.

Boros Ádám több mint húsz terepnapon érintette a területet (BoRos 1973). A Velenceihegységre és a Velencei-tó partmenti és környéki növényzetére vonatkozó figyelemre méltó megfigyeléseit (pl. Minuartia viscosa, Orobanche bartlingii, Nardus stricta, Reseda inodora) herbáriumi példánnyokkal dokumentálta és részben publikálta (BoROs 1937, 1938, 1949), továbbá a térség első növényföldrajzi jellemzését is megfogalmazta (BoROS 1954). BOROS (1938) a Galium mollugo var. vertesense leírásakor a velencei-hegységi („Meleghegy prope Lovasberény") lelőhelyet is megad. Kortársai közül Andreánszky Gábor, Jávorka Sándor, Kárpáti Zoltán, Károlyi Árpád, Lengyel Géza, Polgár Sándor, Vajda László is számos fontos növényfaj előfordulását dokumentálta a Velencei-hegység és környéke területéről, több esetben első megfigyelésként (pl. Andreánszky: Cotoneaster integerrimus, Hippocrepis comosa; Jávorka: Dactylorhiza sambucina, Ornithogalum „pannonicum”, Platanthera chlorantha; Károlyi: Cirsium boujarti; Kárpáti: Sedum caespitosum; Polgár: Rosa hungarica; Vajda: Gagea bohemica). Fekete Gábor a magyar flórára új Chlorocyperus glaber felfedezése (FEKETE 1954) mellett pl. a Peucedanum arenarium-ot és Spiranthes spiralis-t és számos közönségesebb fajt elsőként talált a területen. A terület vegetációkutatásának úttörőjeként felmérte és jellemezte a terület sztyepprétjét, valamint a később erdőssztyepp-tölgyesként azonosított melegkedvelő-tölgyesét és mészkerülő-tölgyesét (FEKETE 1955). Felvételeiben közel 250 db edényes növényfaj szerepel a hegység általa vizsgált mintaterületeiről. A terület erdővegetációjáról a közelmúltban is jelentek meg dolgozatok, FEKETE (2010) a térség természetközeli növényzetének elszegényedéséről ír, BöLÖNI (2010) az átalakuló erdővegetációban felismerhető típusokat ismerteti, KeVEY et al. (2014) a gyertyános-tölgyesek, LENDVAI et al. (2014) a tatárjuharos-tölgyesek felmérésének eredményeiről számol be. FEKETE (1959) doktori értekezésében (kriptogámok- 
kal együtt) már több mint négyszáz faj szerepel a Velencei-hegység és Velencei-tó térségéből, ezt az adatsort gazdagítja UDVARDY \& BÉNYEI-HIMMER (1999), később alig idézett (értékes megfigyeléseket, de sajnos néhány tévedést is tartalmazó) dolgozata. A Liparis loeselii felfedezése (BALOGH 1969) irányította a figyelmet a Velencei-tó úszólápjainak különlegességére, azóta a terület reliktumjellegének bizonyítása, ökológiai, cönológiai és természetvédelmi feldolgozása témákban számos dolgozat született (BALOGH 1971, 1983, 2001, BORHIDI \& BALOGH 1970, BALOGH et al. 1981, Illyés 2006). Az újabb közlemények (pl. Riezing 2002, TAMÁs \& Csontos 2002, CSIKY 2006, IllyÉs \& Tóth 2006, PinKE et al. 2006, BARINA 2008, MolnáR et al. 2017) általában szórványadatokkal gazdagították a terület flórájának ismeretét.

A terület szárazgyepjeinek felvételezése céljából 2000 és 2003 között jártam néhány alkalommal a hegységben, de ekkor kizárólag a sziklagyep- és sztyepprét-foltokat kerestem fel és felvételeztem. 2007-től alkalomszerűen, évente néhány alkalommal, elsősorban a terület déli felén, majd 2012-től intenzíven, a teljes területre irányuló bejárásokat tettem. Ekkor tűztem ki célul a botanikai szakirodalom alapján meglehetősen alulkutatott Velencei-hegység flórájának feldolgozását, növényföldrajzi vonásainak pontosabb feltárását. Mostanra sok növényfaj regionális elterjedési képe, gyakorisága kirajzolódni látszik, több mint ötven, a területről korábban nem jelzett (közölt és/vagy gyüjtött) taxon is előkerült.

A Velencei-hegység edényes flórája a feldolgozott szakirodalmi adatok és saját kutatási eredményeim alapján meghaladja az 1100 taxont (faj, alfaj), de még nem tekinthető egyenletesen feltártnak és jónéhány bizonytalan adat, taxonómiai probléma is tisztázásra vár (terepi és herbáriumi kutatások). Jelen dolgozatban épp ezért részletekbe menő, a flóraelemek százalékos megoszlását értékelő elemzésekbe nem bocsátkozom. A kimutatott fajok teljes listáját, előfordulásának és elterjedési mintázatának hátterében álló okok pontosabb feltárását egy későbbi, statisztikai értékelési módszereket alkalmazó tanulmányban tervezem bemutatni. Jelen közleményben 219 taxon (növényföldrajzi szempontból informatív, ill. a területről eddig nem közölt fajok) jelenleg ismert elterjedési képét, feltérképezett előfordulási adatait mutatom be, valamint felvázolom a hegység növényföldrajzi jellegzetességeit a korábbi közlemények és az új megfigyelések tükrében.

\section{Terület és módszer}

A Velencei-hegység kistáj a Dunántúli-középhegység fő vonulatától délkeletre, a hegység előterében, a Mezőföld síkjából szerényen kiemelkedő dombvidéki jellegű kistáj (DövÉNYI 2010). Valamivel pontosabb a terület lehatárolása a vegetációs középtájak rendszerében (MolNÁR et al. 2008), de jelen dolgozatban a vegetációs középtáj-határt még kicsit kibővítve a geológiai értelemben vett Velencei-hegység (GYALOG \& HORVÁTH 2004) területével foglalkozom (1. ábra). Erre alapozva a Velencei-hegység részének tekintem a Sörédi-hát kistáj déli peremén magasodó gránitdombokat is (1. ábra/A).

A karbonátos kőzetek uralta Dunántúli-középhegység tagjai között a Velencei-hegység földtani adottságai alapján is különleges (GYALOG \& HORVÁTH 2004). A Magyar-középhegység legidősebb tagja, a variszkuszi hegységképződés maradványa. Tönkrögjének legidősebb, felszínen is nyomozható kőzete ópaleozoos agyagpala, amely kisebb-nagyobb foltokban a pátkai Király-berek egy részén, a Sági-hegy-Szűzvári-hegy területén, a Lovasberényierdőben, a Meleg-hegy északkeleti lejtőjén és az Antónia-hegyen, valamint foltszerűen a Bence-hegyen kerül felszínre. A hegység fő tömegét újpaleozoos, Karbon időszaki gránitok alkotják. A gránitterület a felszínen három jól elkülönülő részterületre tagolható: 1) keleti tagja a Sukoró-Velence felett magasodó kelet-velencei egység (1. ábra/C), amely lényegében a Meleg-hegy és környéke gránittömbje, délkeleten a Bence-heggyel, nyugaton a Hurkavölggyel bezárólag. E terület északi és keleti részét, a tágabban értelmezett Lovasberényi- 
erdő területét fiatal üledék, főleg lösz borítja; 2) a Pákozd felett magasodó nyugat-velencei egység (1. ábra/B) a Tompos-hegy-Sár-hegy-Pogány-kő tömbje, amelyet keleten a Laposvölgy, nyugaton a Császár-víz alluviuma határol; 3) a földtani szakirodalomban székesfehérvári-egység (1. ábra/A) néven ismert gránitterület a Császár-víztől nyugatra, kis foltokon felszínre bukkanó szigetszerű gránitdombok (székesfehérvári Csúcs-hegy, Jancsár, Murváshegy) csoportját jelenti. Ez a nyugat felé fokozatosan a Mezőföldbe simuló részterület, tájföldrajzilag a Sörédi-hát része, de fejlődéstörténetileg egyértelműen a Velencei-hegységhez tartozik, ezért jelen dolgozatban annak részeként tárgyalom. A hegység keleti, Nadap és Pázmánd között magasodó szigethegyszerű kiemelkedései (nadapi Nyír-hegy, Csúcsos-hegy, pázmándi Zsidó-hegy, Cseplek-hegy) jóval fiatalabb képződmények. Kialakulásuk középsőfelső-eocén andezitmagmatizmushoz köthető, a felszínre bukkanó sziklákat kőzettanilag különféle kvarcitok alkotják. Ezt a területet a földtani szakirodalomban Nadap-pázmándihegysor (1.ábra/D) néven különböztetik meg.

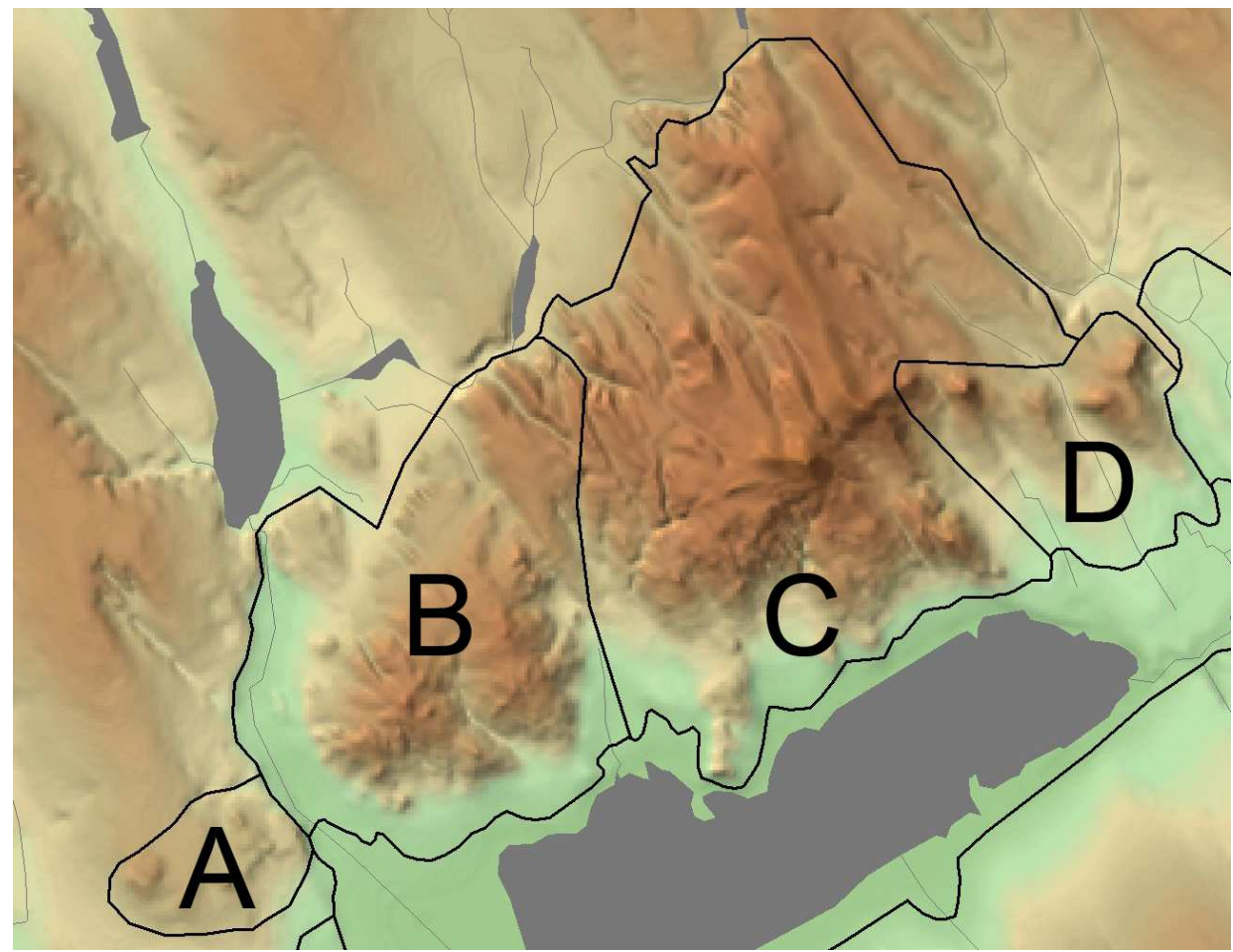

1. ábra A Velencei-hegység vegetációs tájlehatárolása (MolnÁr et al. 2008 után, módosítva), a geológiai részegységek (GYALOG \& HoRVÁTH 2004) határaival; A - Székesfehérvári-egység; B - Nyugat-velencei egység; C - Kelet-velencei egység; D - Nadap-pázmándi hegysor

Fig. 1 The Velence Hills with the borders of geological subregions; A - Székesfehérvár Unit; B - Western Velence Unit; C - Eastern Velence Unit, D = Nadap-Pázmánd Hill Chain

A Velencei-hegységben nagy területeken fiatalabb üledékek vannak felszínen (pl. pannon kvarchomok, gyöngykavics, homokkő, lösz, lejtőhordalék). A Velence-Nadap-Lovasberény vonaltól keletre eső terület egy összefüggő lösztábla része, amelyből valóban csak szigetszerúen emelkednek ki a Nadap-pázmándi-hegysor kvarcithegyei. A Lovasberényi-erdő nyugati részén eolikus-deluviális homok a jellemző alapkőzet. A nyugat-velencei egység és kelet-velencei egység gránittömbje közötti árokban ismét nagy folton a lösz az uralkodó alapkőzet. A nyugat-velencei és kelet-velencei gránitterület nagyon élesen különbözik a felszínén foltokban fennmaradt fiatal üledékek tekintetében. Míg a Sukoró-Velence feletti gránitfelszíneken és 
hegylábi részeken a löszfoltok előfordulása jellemző és gyakori, ettől eltérően a Pákozd feletti gránitfelszíneken inkább pliocén (pannon) kavics, homok és negyedkori proluviális, deluviális üledékek és lejtőtörmelék jellegzetes. Itt a lösz ritka, csak egész kis foltokban nyomozható, a gránittömb peremein, hegylábain. A Császár-víztől nyugatra, a Csúcs-hegy, Jancsár, Murváshegy környékén ismét a lösz a legjellemzőbb fiatal üledék, amelyből csak kis foltokon emelkednek ki a gránitdombok. A Velencei-hegység szélein, a hegyláb, hegységperem már síksági részein, így a Velencei-tó parti sávjában és a kisebb patakvölgyek (Császár-víz, Rovákja-patak, Csont-réti-patak) mentén negyedkori tavi/folyóvízi és mocsári üledékek is jellemzőek. A déli hegylábi részek közvetlenül érintkeznek a Velencei-tavat szegélyező szikes területekkel.

KÁRPÁTI (1960), majd PóCs (1981) növényföldrajzi térképe szerint a Velencei-hegység a Dunántúli-középhegység Veszprimense flórajáráshoz tartozik. BARINA (2004) dolgozata nem tárgyalja a Velencei-hegységet, de a környező, tájföldrajzilag a Mezőföldhöz tartozó részeket sajátos flórával jellemezhető, átmeneti dombvidéki tájként jellemzi, térképe alapján (BARINA 2004, p. 46.) a Velencei-hegység ebben szigetszerűen kimaradó folt.

A terület flóra- és vegetációfejlődése szempontjából a változatos geológiai adottságok (FEKETE 1955) mellett az ember jelenléte ugyancsak meghatározó. A természetszerű erdők és gyepek mellett nagy területeken évszázadok óta jellemző a legeltetés. E tekintetben a hegység gyepes részterületei nagy különbségeket mutatnak. A nyugati, Pákozd feletti területeket (Tompos-hegy, Pákozdi ingókövek térsége) napjainkban is legeltetik, míg a Sukorótól és Velencétől északra fekvő egykori legelőterületeken a gyepek zavartalanabbak, cserjésednek. A települések határában, a domboldalakon a gyümölcsösök és szőlők egyre inkább üdülőterületekké, lakóövezetté alakulnak. A hegység erdőterületein az egyre csökkenő területű természetszerű erdőállományok mellett erdőgazdálkodás során átalakított, de őshonos fafajokból álló gazdasági erdők mellett az idegenhonos fafajok telepített és spontán állományai is egyre nagyobb területeket borítanak. Nagy területeken akácosított erdőállományok állnak, igen gyakori a nyugati ostorfa, de a gyepekre telepített feketefenyvesek is meghatározó elemek a terület jelenlegi arculatában.

A terepi munka során a fontosabbnak ítélt fajok előfordulásait GPS-adatrögzítéssel (több mint tízezer rekord), ill. herbáriumi példánnyal ( 2000) dokumentáltam. A bizonyító példányokat a Magyar Természettudományi Múzeum Növénytárának herbáriumában (BP) helyeztem el. Az enumerációban közép-európai flóratérképezési kvadrátonkénti bontásban (vö. NiKLFELD 1971) település és dűlőnév szerint felsorolom a térképezett lelőhelyeket (turistatérképek és az M1:10.000 topográfiai térképek névanyagát követve; dűlőnév-rövidítések az enumerációban: hegy: h.; völgy: v.; domb: d.; erdő: e.). Amennyiben figyelemre érdemes, megjegyzést teszek a taxon jellemző élőhelyére, regionális gyakoriságára vonatkozóan is. A különálló lelőhelyeket pontosvessző választja el egymástól. A lelőhelyek felsorolását követően megadom a taxon korábbi publikált adatainak hivatkozását. A regionálisan ritka növények esetén felsorolom a korábban gyűjtött herbáriumi példányaik legfontosabb adatait is (Herb. Gyüjtö, gyüjtés éve, lokalitás). A korábbi gyüjtéseket az MTM Herbarium Carpato-Pannonicum törzsgyüjteményének 2019 januárjában és februárjában történt átnézése alapján idézem. A területről korábban nem dokumentált, a hegységre új taxonok az enumerációban félkövér szedéssel szerepelnek. A dolgozatban az egyes fajok elterjedését bemutató térképeken (213. ábra) a gps-eszközzel (Trimble Juno 3B, Mobile Mapper 6) gyüjtött saját adatok mellett, a jelkulcsban megkülönböztetett módon megjelenítem a korábbi publikált és herbáriumi adatokat is. A dolgozatban szereplő térképeket QGIS 2.16 (QGIS Development Team 2016) szoftver segítségével állítottam elő.

A taxonok nómenklatúrája az Euro+Med Plantbase-t követi (Euro+Med 2006-), ettől eltérő említés esetén a követett forrást az adott taxonnál jelzem. Az említett taxonok areájára vonatkozó megjegyzéseket Meusel et al. $(1965,1978)$, MeuSEl \& JäGER (1992), Horváth et al. 
(1995) és az Euro+Med Plantbase (Euro+Med 2006-) megállapításaira és areatérképeire alapozom. A növényföldrajzi összegzésben az elterjedési mintázatok megfogalmazásakor több esetben praktikusnak mutatkozott a Velencei-hegység földtani szakirodalomban fentebb idézet felosztása, így ahol ezekkel megfogható volt a belső mintázat, ott ezeket a terminusokat is használtam.

\section{Eredmények}

A Velencei-hegység flórájának jellemzői

A Velencei-hegység flórájában és vegetációjában, kis területe és a domborzatára jellemző szerény magasságkülönbségek ellenére, sajátos mintázatok mutathatók ki. A klimatikus adottságok tekintetében egységes területen e mintázatok hátterében a geológiai és a felszínalaktani sajátosságok, a különböző irányból határos területek vegetációjának különbségei (sziki, lösz-, ill. homoki vegetációfoltok) emelhetők ki, de egyes fajok esetében meghatározónak látszik az egyes részterületek tájhasználatának története is.

A hegység flórájának egyedi karakteréhez a kontinentális és szubmediterrán fajok nagyon markáns együttes jelenlétén, a bázikus és acidofil termőhelyek mozaikos egymásmellettiségén túl az is hozzájárul, hogy számos, hazánkban közönséges mezofil erdei faj hiányzik a területen. Alább a hegység növényföldrajzi karakterét leginkább meghatározó flóraelem-csoportok jellemző képviselőinek említésével igyekszem bemutatni a terület sajátosságait; 1) pannon (szub)endemizmusok; 2) balkáni és pannon-balkáni areájú taxonok; 3) keleti (kontinentális) sztyeppfajok; 4) a szubmediterrán fajok, amelyek között szintén a keleti elterjedési súlypontú, pontusz-mediterrán és kelet-mediterrán elemek jellemzőbbek a területen. Végül, 5) a terület flórájának további karakteradó fajai, vonásai részfejezetben a többi flóraelemcsoportból néhány, a területre jellemzőbb faj növényföldrajzi jelentőségét tárgyalom. A flóraelem-csoportok tárgyalása során a csoportosítás alapja a Velencei-hegységen belül tapasztalt regionális elterjedési mintázat és másodsorban a hasonló élőhely-preferencia volt.

\section{Pannon (szub)endemizmusok}

A Velencei-hegység flórájának talán legnevezetesebb növénye a Scilla bifolia alakkör hexaploid taxonja, a Nadap melletti Templom-hegyről gyüjtött minták alapján leírt $S$. spetana Kereszty (KERESZTY et al. 1986). KERESZTY (1993) a locus classicuson kívüli velencei-hegységi herbáriumi példányait is $S$. spetana-nak tartja (megjegyzem, hogy morfológiailag változatosak a populációk, a határozóbélyegek alapján az azonosítás nem mindig egyértelmú). A taxon faji önállóságára vonatkozóan megosztottság jellemző (vö. Euro+Med Plantbase, The Plant List), dolgozatomban TRÁvNíčEK et al. (2009) eredményeit fogadom el. E munka a hexaploid taxont alfaji szinten tárgyalja és azt is bizonyítja, hogy a taxon nem a Velencei-hegység endemizmusa, Magyarországon más lelőhelyeken, továbbá Ausztriában, Horvátországban, Szlovákiában és Csehország morvaországi részén is kimutatták jelenlétét.

A terület növényföldrajzi vonásainak megfogalmazása szempontjából fontosabb pannon flóraelemek közül több taxon gyakori, vagy általánosan elterjedt a területen. Így a Velenceihegység erdőterületein közönséges a már JÁVORKA (1940) által is különös figyelemben részesített Helleborus dumetorum (8677.4, 8777.1, 8777.2, 8777.3, 8777.4), szárazgyepjeiben gyakori a Centaurea scabiosa subsp. sadleriana. A területen ugyancsak általánosan elterjedt a Dianthus pontederae; itteni törpe alakjára („var. pusillus”) már BoRos (1954) felhívta a figyelmet. A Velencei-tó partmenti rétjein gyakori, de a Velencei-hegység hegylábi rétjein, mocsa- 
raiban máshol is jellemző alföldi súlypontú bennszülött fajok a Cirsium brachycephalum (8777.3, 8777.4, 8877.1) és az Achillea asplenifolia. A ritkább, ill. a térségben szórványos pannon endemizmusok közé tartozik a közelmúltban leírt Sempervivum matricum. LETZ (2009) a pannon-balkáni Sempervivum marmoreum taxonból választotta le a hazánkban és Szlovákiában előforduló alakot. Habár a S. marmoreum előfordulása a Velencei-hegységben régóta ismert (KERNER 1870a, FEKETE 1955), Roman Letz a taxonómiai revízió során a térségből származó példányokat, mintákat nem használt. A Velencei-hegységben igen ritka Sorbus danubialis areájáról ugyan megoszlanak a vélemények, de e taxont SomLYAY \& SENNIKov (2015) munkája alapján a pannon fajok között említem.

\section{Pannon-balkáni és balkáni elemek}

A pannon-balkáni, balkáni elterjedésű fajok között a terület tölgyeseinek jellemző és gyakori elemei a Doronicum hungaricum (2. ábra) és a Polygonatum latifolium. Növényföldrajzilag különösen jelentős a Bupleurum pachnospermum, amely hazánkban talán sehol sem olyan gyakori, mint a Velencei-hegységben. A hegység délkeleti felének szárazgyepjeiben szinte általános elem, de löszhatású szárazgyepekben a hegység északi peremterületein is előfordul (3. ábra). A térképezés jelen állása szerint a Rosa hungarica inkább a hegység déli felének xerotherm cserjéseiben jellemző. Az Ornithogalum comosum regionális elterjedése a hegység keleti felének jó állapotú sztyepprét-maradványaira koncentrálódik (4. ábra). Jóval kevesebb ponton került elő a Cirsium boujartii és a Verbascum speciosum.

\section{Keleti (kontinentális) sztyeppfajok}

A Velencei-hegység növényföldrajzi képében meghatározó a kontinentális sztyeppfajok (ide értem kontinentális flóraelemeken túl a pontuszi és pontusz-pannon elterjedésű fajokat is) nagyszámú és gyakran tömeges jelenléte. Sok Magyarországon alföldi súlypontú sztyeppfaj (pl. Achillea ochroleuca, A. setacea, Artemisia pontica, Marrubium peregrinum) előfordulása ismert a Velencei-hegységben, ugyanakkor változó gyakorisággal az inkább kollin-szubmontán (középhegységeinkben jellemzőbb) kontinentális fajok (pl. Bupleurum affine, Carex humilis, Cotoneaster niger, Iris pumila, Jurinea mollis, Lactuca viminea, Minuartia setacea, Scorzonera purpurea, Seseli hippomarathrum, Stipa dasyphylla) is megtalálhatók a területen.

A pontuszi-kazakisztáni sztyeppek karakterisztikus faja, az Artemisia austriaca Magyarországon elég szórványos, de velencei-hegységi gyakorisága régóta jól ismert (vö. Kitaibel, 1816: "bei Sukoró sind die Hügel und Anhöhen ganz grau von Artemisia austriaca" LőKös 2001) jelenség. A faj a terület nagy részének sztyepprétjein, legelőin szinte általános elem. A térképezés jelen állása szerint azonban ez a gyakori előfordulás a hegység déli-délkeleti felére igaz, meglepő módon úgy tűnik, hiányzik a Nadap-pázmándi-hegysor néven ismert keleti kvarcithegyeken (pl. nadapi Csúcsos-hegy, pázmándi Zsidó-hegy) és a hegység északnyugati gyepterületén (Pátka: Király-berek térsége) (5. ábra). Nagyon hasonló elterjedési mintázatot mutat a Carex supina és az Anthemis ruthenica is. Ezzel szemben egyes keleti fajok (Aster amellus, Linum hirsutum) keleti-északkeleti súlypontot mutatnak. [FEKETE (1955) a Festucetum sulcatae 3. cönológia felvételében Pákozdról („oberhalb Pákozd, auf Quarzit”) is jelzi az Aster amellus előfordulását, a cikkben azonban tévesen szerepel a helyszín, a 3. cönológiai felvétel valójában Pázmánd határából származik!] A Linum hirsutum a Nadap-pázmándi-hegysor területén túl, a Lovasberény melletti homok- és löszgyepekben is gyakori.

Az alföldi és középhegység-peremi löszgyepek jellemző sztyeppfajai közül a terület szárazgyepjeiben az Euphorbia nicaeensis subsp. glareosa általánosnak mondható. Az Agropyron 
cristatum, Cytisus austriacus, Jurinea mollis, Linaria biebersteinii, Silene bupleuroides, Taraxacum serotinum, Viola ambigua a hegységperem löszgyepjeire és részben belső területek löszhatású szárazgyepjeire koncentrálódik, de állományaik többsége a hegység keleti felében található. Ezeknél ritkább a Hypericum elegans, amely a Lovasberényi-erdő északi peremvidékének löszdombjain elég gyakori, de a keleti és nyugati peremterület szárazgyepjeiben csak egy-egy populációja ismert (6. ábra). Az Ajuga laxmannii és a Reseda inodora csak egy-két kis kiterjedésű folton fordul elő a hegység északkeleti harmadában.

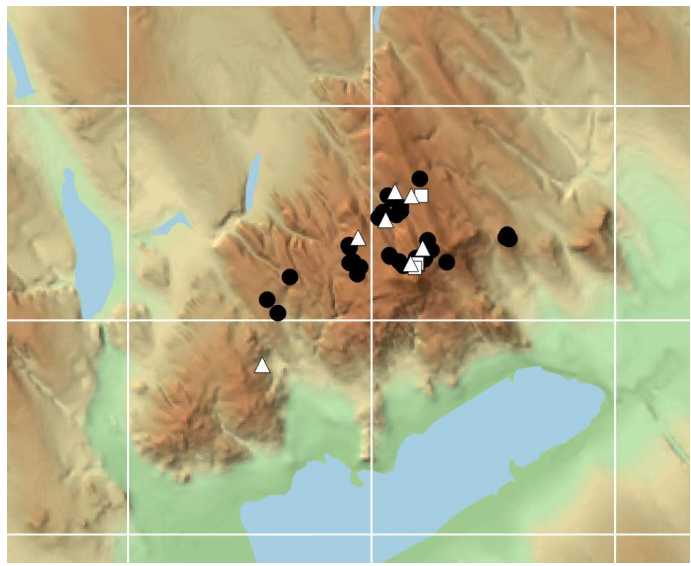

2. ábra A Doronicum hungaricum elterjedése a

Velencei-hegységben (fekete kör: saját terepi adat; fehér négyzet: korábbi herbáriumi adat; fehér háromszög: korábbi publikált adat)

Fig. 2 Distribution of Doronicum hungaricum in the Velence Hills (black circle: own record; white square: former herbarium record; white triangle: former literature record)

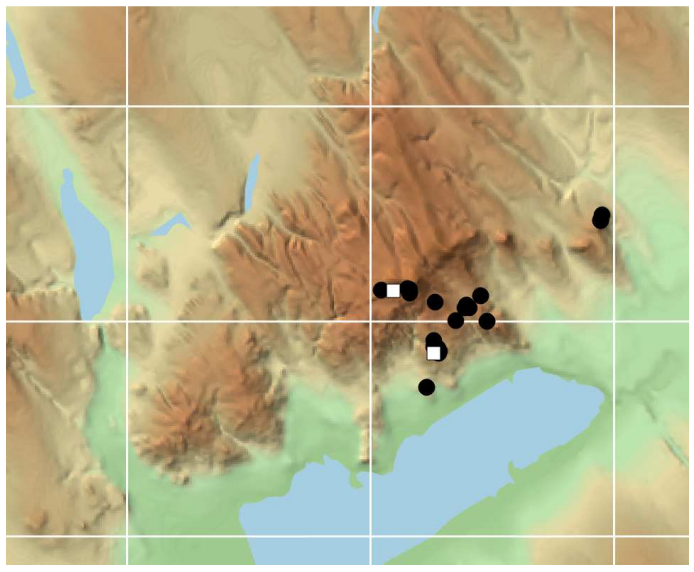

4. ábra Az Ornithogalum comosum elterjedése a Velencei-hegységben (fekete kör: saját terepi adat; fehér négyzet: korábbi herbáriumi adat; fehér háromszög: korábbi publikált adat)

Fig. 4 Distribution of Ornithogalum comosum in the Velence Hills (black circle: own record; white square: former herbarium record; white triangle: former literature record)

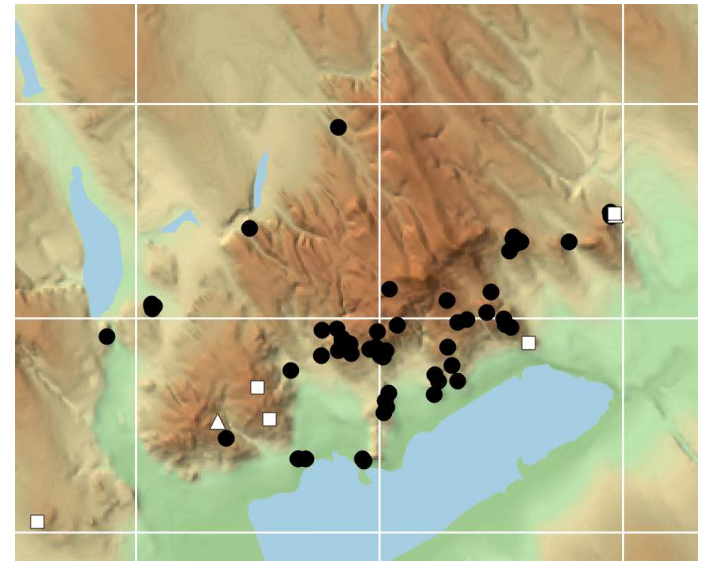

3. ábra A Bupleurum pachnospermum elterjedése a Velencei-hegységben (fekete kör: saját terepi adat; fehér négyzet: korábbi herbáriumi adat; fehér háromszög: korábbi publikált adat)

Fig. 3 Distribution of Bupleurum pachnospermum in the Velence Hills (black circle: own record; white square: former herbarium record; white triangle: former literature record)

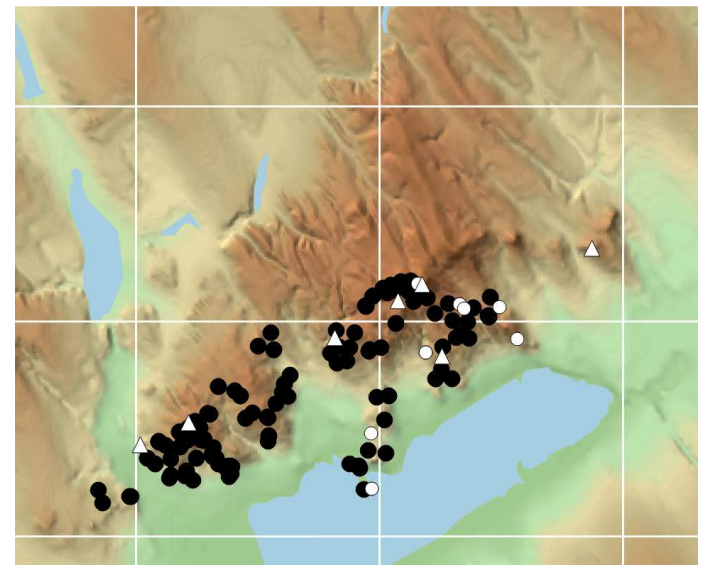

5. ábra Az Artemisia austriaca elterjedése a Velencei-hegységben (fekete kör: saját terepi adat; fehér négyzet: korábbi herbáriumi adat; fehér háromszög: korábbi publikált adat)

Fig. 5 Distribution of Artemisia austriaca in the Velence Hills (black circle: own record; white square: former herbarium record; white triangle: former literature record) 
A homokpusztarétek mészkedvelő fajai is a kelet-velencei egység szórványos (Astragalus asper, Oxytropis pilosa, Peucedanum arenarium), ill. ritka (Minuartia glomerata) elemei. A legtöbb ilyen faj Sukoró és Pákozd között a Rigó-hegy-Csúcsos-hegy-Külső-hegy szőlőhegy-peremi sztyepprét-maradványain összpontosul. A homokpusztai fajok más része azonban a hegység déli felében, a nyugati perem gránitdombjaitól a Nadap-pázmándi-hegysorig végig előfordul sztyeppréteken. Ilyen faj az Achillea ochroleuca, de a napjainkra (a legeltetés viszszaszorulása miatt) erősen megritkult Alyssum turkestanicum herbáriumi példányok alapján kirajzolódó elterjedése (7. ábra) is ilyen, csak sokkal sporadikusabb mintázatot mutat. Mostanában csak a Tompos-hegy nyugati-délnyugati részén került elő.

A középhegységi sztyepprétek, erdőssztyepp-maradványok keleti fajai közül a hegység teljes területén általános az Inula oculus-christi, Stipa capillata, valamennyi részterületen előfordul, de kopárosodott gránitfelszíneken ritka a Carex humilis. A Cytisus ratisbonensis a hegység több részterületén előkerült, de regionálisan ritka elem. A Stipa dasyphylla a keletvelencei egység jobb sztyepprétfoltjain gyakori, a Velencei-hegység más területein hiányzik. Említést érdemlő, de a hegységben igen ritka középhegységi súlypontú sztyepp- és sziklagyep-fajok a Stipa tirsa, Pulsatilla grandis és a Scorzonera austriaca.

A pontuszi erdőssztyepp-fajok (pl. Achillea pannonica, Adonis vernalis, Arum orientale, Euphorbia salicifolia, Glechoma hirsuta, Inula germanica, Iris variegata, Vinca herbacea) a táj vegetációjából adódóan a hegység északi-északkeleti felében, a lösz erdőssztyepp-tölgyes területén koncentrálódnak, ugyanakkor déli és nyugati részeken csak sporadikusak, némelyikük a Pákozd feletti „,ösztelen” legelőkön nagy területeken hiányzik is. Elterjedési mintázatukat az Adonis vernalis és Vinca herbacea elterjedése szépen illusztrálja (8. ábra). A hegység északi felének ritkább eleme a Phlomis tuberosa.

A sztyeppcserjések uralkodó fajai közül a Prunus fruticosa a hegység valamennyi nagyobb részterületén előfordul, a nyugat-velencei egység Pákozd feletti gránitterületén hiányzik, csak ennek hegylábi területén került elő. A Prunus tenella a kelet-velencei egység középső és déli felének xerotherm erdőssztyepp élőhely-maradványain koncentrálódik, de megjelenik a hegység székesfehérvári-egység löszhatású területein is. A Rosa spinosissima ritka, délkeleti súlypontú elem a hegységben, a térképezés jelen állása szerint úgy tűnik, hogy a Mészeghegy-Hurka-völgy vonaltól keletre fordul elő.

\section{Szubmediterrán elemek, a pontusz-mediterrán és kelet-mediterrán fajok túlsúlyával}

A Velencei-hegység flórájában igen jelentős a szubmediterrán flóraelem-csoportokba tartozó fajok száma. A szubmediterrán elemek között itt egyértelmúen a délkeleti elterjedési súlypontú pontusz-mediterrán elemek (melegigényes sztyeppfajok a kelet-mediterrán területekre is kiterjedő areával) és azok a szubmediterrán elemek a meghatározóak, amelyek elterjedése a Fekete-tenger medencéjéig (vagy tovább keletre) is elér.

A hegység szárazgyepjeiben általánosan előforduló pontusz-szubmediterrán sztyeppfajok a Ranunculus illyricus, a Seseli pallasii, az Asparagus officinalis. Hasonlóan elterjedt, de a nyugati részeken ritkább az Galatella linosyris. A Gagea bohemica a hegység gránitterületein a sziklagyepektől a bokorerdőkig valóban elég gyakori. A déli szárazgyep-vonulat sztyepprétjein végig megvan az Allium flavum, Achillea nobilis subsp. neilreichii, különösen legelőterületeken (incl. egykori ) az Echium italicum és a Trifolium retusum. Ugyanitt, a hegység déli felében Székesfehérvártól Pázmándig cserjésekben és erdőszegély-élőhelyeken fordul elő a Rosa gallica. Bolygatott gyepekben, szántószegélyeken a Vicia striata is ebben a zónában a legjellemzőbb. Az Odontites luteus a kelet-velencei egység területének sztyepprétjein általános. A hegység területén lokális, egy-néhány ponton előkerült pontusz-mediterrán fajok a Crupina vulgaris, a Scorzonera hispanica és a Trifolium diffusum. 


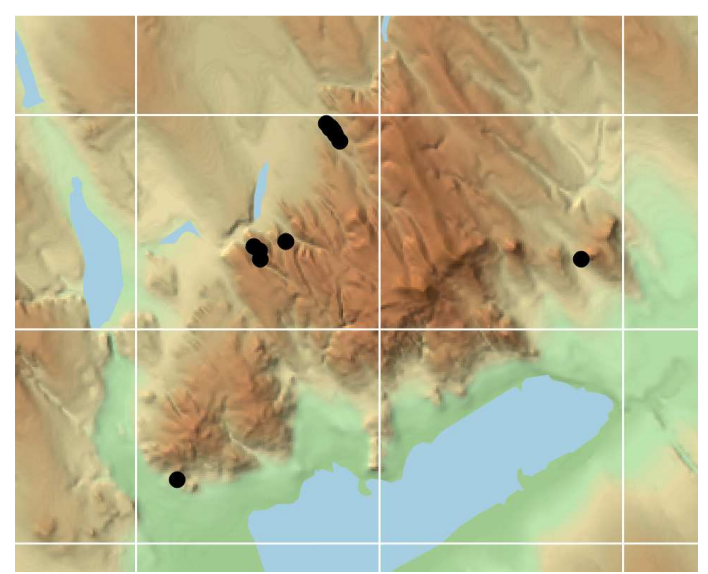

6. ábra A Hypericum elegans elterjedése a

Velencei-hegységben (fekete kör: saját terepi adat; fehér négyzet: korábbi herbáriumi adat; fehér

háromszög: korábbi publikált adat)

Fig. 6 Distribution of Hypericum elegans in the Velence Hills (black circle: own record; white square: former herbarium record; white triangle: former literature record)

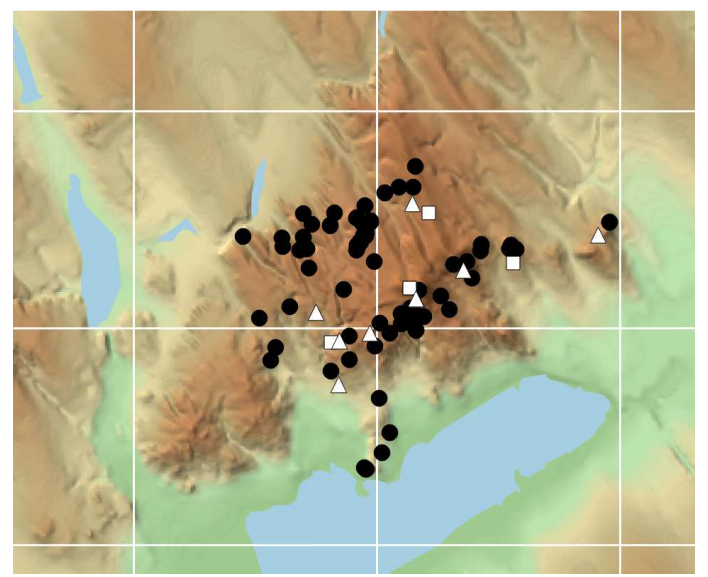

8. ábra A Vinca herbacea elterjedése a Velenceihegységben (fekete kör: saját terepi adat; fehér négyzet: korábbi herbáriumi adat; fehér háromszög: korábbi publikált adat)

Fig. 8 Distribution of Vinca herbacea in the Velence Hills (black circle: own record; white square: former herbarium record; white triangle: former literature record)

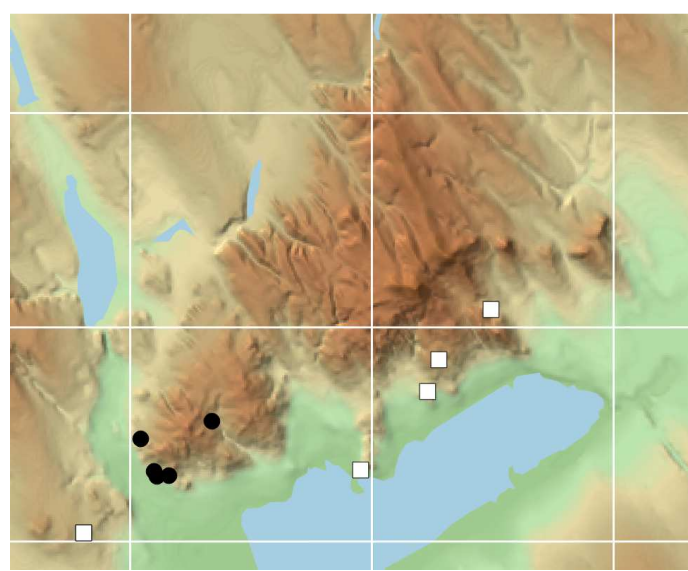

7. ábra Az Alyssum turkestanicum elterjedése a Velencei-hegységben (fekete kör: saját terepi adat; fehér négyzet: korábbi herbáriumi adat; fehér háromszög: korábbi publikált adat)

Fig. 7 Distribution of Alyssum turkestanicum in the Velence Hills (black circle: own record; white square: former herbarium record; white triangle: former literature record)

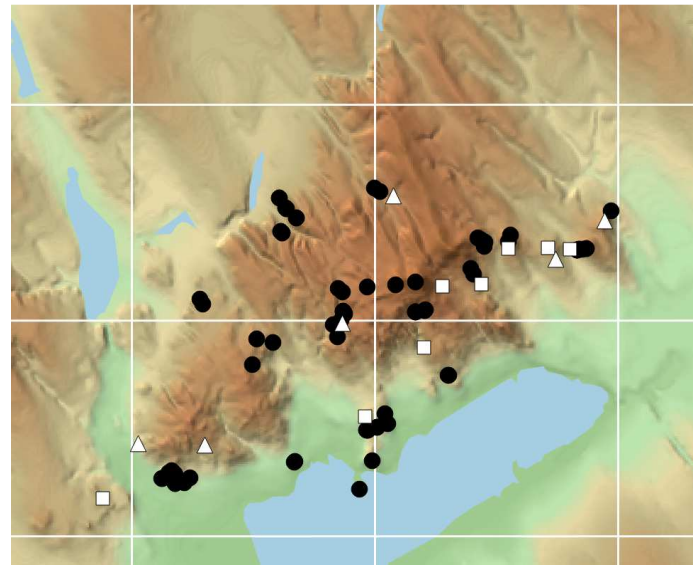

9. ábra A Sternbergia colchiciflora elterjedése a Velencei-hegységben (fekete kör: saját terepi adat; fehér négyzet: korábbi herbáriumi adat; fehér háromszög: korábbi publikált adat)

Fig. 9 Distribution of Sternbergia colchiciflora in the Velence Hills (black circle: own record; white square: former herbarium record; white triangle: former literature record)

A hegység erdőssztyepp-tölgyes állományaira jellemző szubmediterrán elemek (Aegonychon purpurocaeruleum, Piptatherum virescens, Smyrnium perfoliatum) jelentőségét már FEKETE (1955) hangsúlyozza; többek között e fajok miatt azonosította kezdetben a Velenceihegység Lovasberényi-erdő térségében koncentrálódó meleg termőhelyű tölgyeseit a középhegység melegkedvelő-tölgyesével, csak később, Zólyomi Bálinttal folytatott diskurzusaikat követően ismerte fel, hogy az állományok a lösztölgyesekhez tartoznak (vö. FEKETE 2010). A 
tölgyes erdőszegélyek igen ritka elemeként a Bupleurum praealtum is előkerült. A Cotinus coggygria előfordulása inkább a hegység déli felére jellemző. A Velencei-hegység löszhatású szárazgyepjeiben, bokorerdeiben, erdőszegélyein általánosan előfordul a Sternbergia colchiciflora (9. ábra). E faj nagyobb foltokon csak a zárt erdőterületeken, valamint a nyugat-velencei egység erodált talajú, erősen legeltetett gránitfelszínein hiányzik. A szubmediterrán sztyepprétek jellemző fajai közül a hegységben általános az Allium sphaerocephalon, a Convolvulus cantabrica, gyakori az Aira elegantissima, Chrysopogon gryllus, Cleistogenes serotina és a Draba muralis. A térképezés eddigi eredményei szerint a Petrorhagia saxifraga súlypontosan a nyugat-velencei egység területén jellemző a kistájban.

Az országosan ritka Herniaria incana a Velencei-hegység déli, xerotherm élóhelyekben gazdag vonulatain jellemző szubmediterrán faj, sztyeppréteken és útszéleken szórványos. Hasonlóan a déli peremek ritka eleme a Medicago monspeliaca. A Velencei-hegység flórájának különleges, sokszor hangsúlyozott (KÁRPÁTI 1934, BOROS 1937, 1954) szubmediterrán eleme a Sedum caespitosum, a déli peremterület kis magasságú dombjain, hegylábfelszínén 18 ponton került elő (10. ábra). A Lathyrus sphaericus regionális elterjedése viszont csak a kelet-velencei egységre és Nadap-pázmándi-hegysorra korlátozódik, a sukorói Csúcsos-hegy - Meleg-hegy - nadapi Csúcsos-hegy - velencei Bence-hegy által körülhatárolható területen koncentrálódik, de itt elég gyakori (11. ábra). A szubmediterrán flóra további, növényföldrajzi szempontból nagy jelentőségü, de a területen ritka elemei az Anacamptis pyramidalis, Bombycilaena erecta, Globularia bisnagarica, Ononis pusilla, Trinia glauca, Veronica praecox.

A szubatlantikus és atlanti-mediterrán areájú fajok csak kis számban fordulnak elő a területen, de pl. a Jasione montana a gránit kisavanyodó sziklás gyepjeiben gyakori (KERNER 1872b: „ziemlich haufig”), a Genista pilosa pedig a mészkerülő-tölgyes foltok egyik tömeges karakterfaja (BOROS 1954, FEKETE 1955). A területen ritka, de növényföldrajzilag igen fontos további atlanti-mediterrán elemek a Hippocrepis comosa, Spiranthes spiralis és a Valeriana dioica.

\section{A terület flórájának további karakteradó fajai, vonásai}

Habár a Velencei-hegység erdeinek elszegényedését, fajkészletének kiüresedését a terület vegetációját több mint fél évszázaddal ezelőtt feldolgozó Fekete Gábor maga is hangsúlyozza (FEKETE 2010), még ma is állítható, hogy a középhegységi száraztölgyes-fajok gazdagon képviseltek a területen. A fentebb már említett fajokon túl a terület erdőssztyepp-tölgyeseinek a karakterisztikus - változó gyakoriságú - elemei a Cyanus triumfettii, Erysimum odoratum, Fragaria moschata, F. viridis, Iris variegata, Lactuca quercina, Orchis purpurea, Peucedanum alsaticum, P. cervaria, Polygonatum odoratum, Pulmonaria mollis. A hegység egyik leggyakoribb, általánosan elterjedt erdei faja a Corydalis pumila. FEKETE $(1955,1959)$ korábbi dolgozataiban a Corydalis solida is szerepel néhány mintaterületről, de ezt a fajt újabban nem sikerült megerősíteni a területről.

A mezofil erdei fajok fajgazdagsága azonban messze elmarad a Dunántúli-középhegység valamennyi más területén jellemzőtől. FEKETE (1955) is említ egy fragmentális gyertyánostölgyest, KeVEY et al. (2014) is szegényes gyertyános-tölgyesekről számol be. A Velenceihegységben a Corydalis cava gyakori, de a további jellemző mezofil erdei fajok többsége (pl. Aegopodium podagraria, Anemone ranunculoides, Bromopsis benekenii, Campanula trachelium, Carex sylvatica, Cephalanthera damasonium, Gagea lutea, Epipactis microphylla, E. voethii, Galanthus nivalis, Galium odoratum, Isopyrum thalictroides, Mercurialis perennis, Rumex sanguineus, Schedonorus giganteus, Scrophularia nodosa, Stachys sylvatica, Viola reichenbachiana) regionálisan szórványos vagy ritka elem. Habár BoRos (1954) szerint „a Velencei-hegység tölgyeseinek és gyertyános-tölgyeseinek növényzete alig különbözik a Vértes dolomitján és mészkövén élő megfelelő erdőktől", ez a megállapítása vitatható. Növényföldrajzi értékelésekben ugyanis jelentős a hiányflóra (azaz a hasonló helyeken a környező tájak területén jel- 
lemző, de a vizsgált területen hiányzó fajok) jelzésértéke is (JÁVORKA 1940, MÁTHÉ 1940, 1941, ZóLYOMI 1942, BAUER 2014). Ilyen szempontból a különbség igen nagy a Dunántúli-középhegység bármelyik másik tájegységével szemben, hiszen a Velencei-hegységből nemcsak az igazán montán fajok hiányoznak (ill. eddig nem kerültek elő), de olyan, a Dunántúli-középhegységben közönségesebb mezofil erdei/Fagetalia fajok is, mint Adoxa moschatellina, Lathyrus vernus, Pulmonaria officinalis stb.

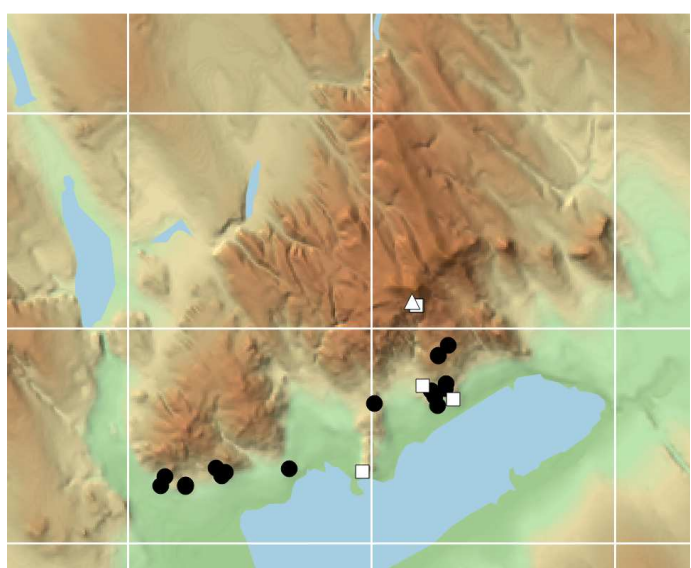

10. ábra A Sedum caespitosum elterjedése a Velencei-hegységben (fekete kör: saját terepi adat; fehér négyzet: korábbi herbáriumi adat; fehér háromszög: korábbi publikált adat)

Fig. 10 Distribution of Sedum caespitosum in the Velence Hills (black circle: own record; white square: former herbarium record; white triangle: former literature record)

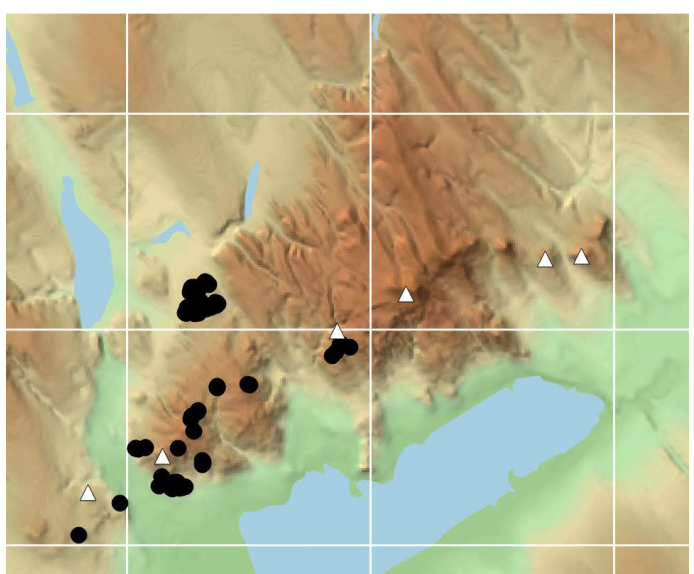

12. ábra A Scabiosa canescens elterjedése a Velencei-hegységben (fekete kör: saját terepi adat; fehér négyzet: korábbi herbáriumi adat; fehér háromszög: korábbi publikált adat)

Fig. 12 Distribution of Scabiosa canescens in the Velence Hills (black circle: own record; white square: former herbarium record; white triangle: former literature record)

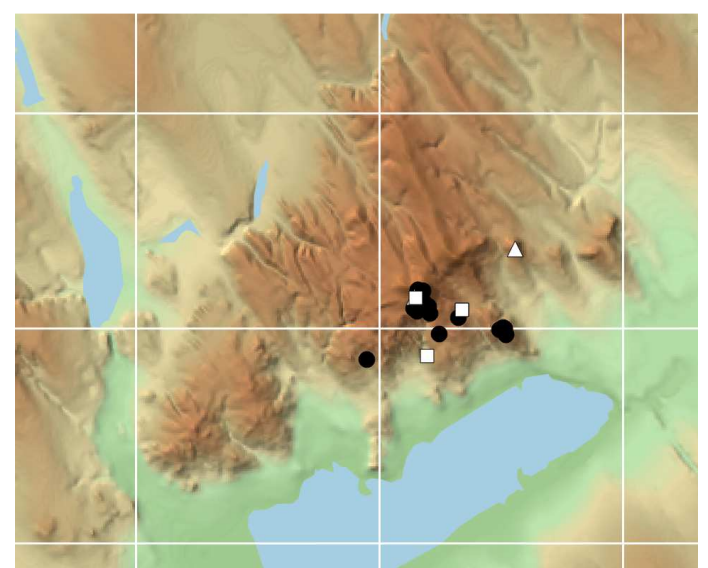

11. ábra A Lathyrus sphaericus elterjedése a Velencei-hegységben (fekete kör: saját terepi adat; fehér négyzet: korábbi herbáriumi adat; fehér háromszög: korábbi publikált adat)

Fig. 11 Distribution of Lathyrus sphaericus in the Velence Hills (black circle: own record; white square: former herbarium record; white triangle: former literature record)

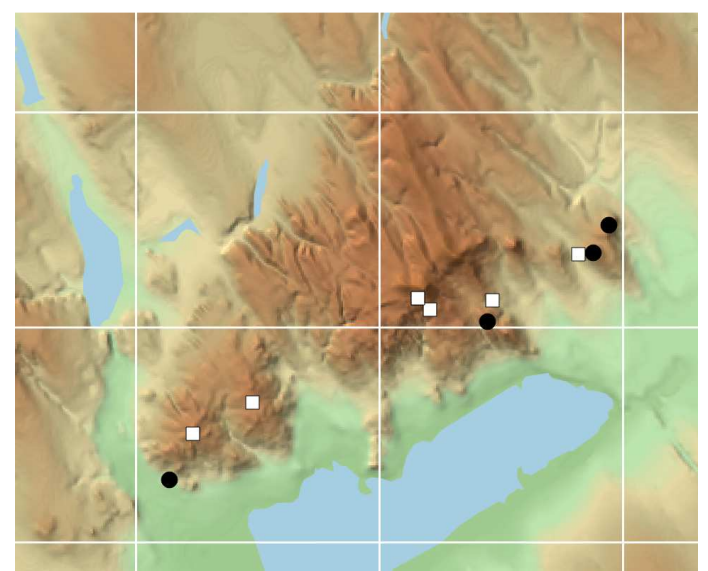

13. ábra A Minuartia viscosa elterjedése a Velencei-hegységben (fekete kör: saját terepi adat; fehér négyzet: korábbi herbáriumi adat; fehér háromszög: korábbi publikált adat)

Fig. 13 Distribution of Minuartia viscosa in the Velence Hills (black circle: own record; white square: former herbarium record; white triangle: former literature record) 
Szárazabb termőhelyű tölgyesek terén is fontos eltérések vannak, a Velencei-hegységből úgy tűnik, hiányzik a Primula veris, Bupleurum falcatum. Érdekes adat viszont a közép-európai areájú, de hazánkban nagy növényföldrajzi jelentőségü Potentilla micrantha, amely KEVEY et al. (2014) egyik cönológia felvételében szerepel, a pákozdi Belső-erdő területéről. A fajjal a hegységben eddig nem találkoztam, e megfigyelés ellenőrizendő, megerősítés esetén feltétlenül herbáriumi példánnyal dokumentálandó.

A Velencei-hegységben kevés fajra jellemző elterjedési képet mutat a Scabiosa canescens (12. ábra). A nyugat-velencei egység területén elég gyakori, máshol csak néhány sekély talajú gránit- és kvarcitfelszínen bukkan fel, leginkább ott, ahol a lösz hiányzik és inkább homok, ill. aprótörmelékes lejtőüledék jellemző a talaj szerkezetére. A Scabiosa canescens hasonló preferenciát mutat a Dunántúli-középhegység dolomitterületein is (pl. Bakony-vidéken): a löszlepellel fedett foltokon hiányzik, ellenben a kopár dombhátakon, dolomitmurvás és homokos sekély talajú gyepekben elég gyakori. Itt érdemel említést a hasonló élőhelypreferenciájú, de a Velencei-hegységben ritka Alyssum montanum, Jovibarba globifera subsp. hirta, Saxifraga tridactylites is.

A Velencei-hegység grániton kialakult, sekély talajú gyepjeiben elég gyakori kísérőfajok a Polycnemum arvense, Spergularia rubra, Vulpia myuros, Veronica dillenii és a Filago minima, utóbbi faj főleg a nyugat-velencei egység területén. A Magyarországon nagyon ritka Minuartia viscosa-ról BoRos (1954) még a „kiritkuló” Festuca pseudovina-gyepek jellemző fajaként ír. A M. viscosa napjainkra erősen megritkult, de az elmúlt évek terepbejárásai során néhány ponton a hegység déli szárazgyep-területein újra előkerült (13. ábra).

FEKETE (1955) a montán elemek teljes hiányát hangsúlyozza. A hegységre általában igaz megjegyzés ellenére előfordul néhány, hegyvidéki súlypontú faj a területen. A montán karakterú Nardus stricta a Velencei-hegység meglepő ritkasága, edafikus maradványélőhelyei a Tompos-hegy magasabb részein található üde, időszakosan forrásos mélyedések gyepjei, ahonnan jelenlétét már BoRos (1949) közölte. A Magyarországon szintén inkább hegyvidéki Gentiana cruciata a Velencei-hegységben ritka színezőelem, eddig csak a nadapi Csúcsoshegy (ILlYÉs \& BöLÖNI 2007) és Bence-hegy északi lejtőjének cserjésedő félszárazgyep-maradványaiban került elő.

A Velencei-hegység flórájában is egyre nagyobb számban vannak jelen idegenhonos fajok, részben özönfajok. Ezek növényföldrajzilag kisebb jelentőségúek, ezért a térképezés során feljegyzett taxonokat itt csak felsorolásszerúen adom meg: Abutilon theophrasti, Acer negundo, Ailanthus altissima, Amorpha fruticosa, Asclepias syriaca, Symphyotrichum lanceolatum, Symphyotrichum $\times$ salignum, Bidens frondosus, Cannabis sativa, Celtis occidentalis, Elaeagnus angustifolia, Fallopia baldschuanica, Fallopia $\times$ bohemica, Gleditsia triacanthos, Helianthus tuberosus, Juglans nigra, J. regia, Lunaria annua, Lycium barbarum, Mahonia aquifolium, Morus alba, Opuntia cf. phaeacantha, Padus serotina, Panicum capillare, Parthenocissus inserta, Robinia pseudoacacia, R. viscosa, Ruta graveolens, Solidago gigantea, S. canadensis, Symphoricarpos albus, Tamarix tetrandra, Tilia argentea.

\section{A vegetáció vázlatos jellemzése}

A hegység erdeit FEKETE (1955) még a mainál jobb állapotban felvételezte. Az újabban született dolgozatokkal együtt (KeVEY et al. 2014, LENDVAI et al. 2014) állítható, hogy a terület lösztölgyeseit, mészkerülő-tölgyeseit, fragmentális gyertyános-tölgyeseit és állapotuk változásának irányát (BÖLÖNI 2010, FEKETE 2010) elég jól ismerjük.

Az erdőkre vonatkozóan FEKETE (1955) által kimutatott kettősség (mészkedvelő ill. acidofil típusok) a terület szárazgyepjeiben is megmutatkozik. Ennek hátterében is elsősorban löszhatás, ill. a gránit/pala/kvarcit felszínek erodáltságának mértéke áll. BoRos (1954) így fo- 
galmaz: „... másutt a hajlatokban, a gránit között némi lösz ül meg. Ilyen helyeken mészkerülő és mészkedvelő növények keverednek". Habár az összefoglaló művek a Velencei-hegységet általában uralkodó alapkőzete miatt a Dunántúli-középhegységben ritka, mészkerülő vegetációtípusokkal jellemzik, igazán acidofrekvens gyepvegetáció csak az erodált felszínú és szinte talajmentes sziklakibúvásokon, dombtetőkön és meredekebb lejtőkön áll. A löszhatás a Lovasberényi-erdő térségében (lényegében egy önálló lösztáblán áll) és a Mezőfölddel érintkező hegységperemi, hegylábi részeken a legmarkánsabb, de foltszerűen a belső gránit-területeken is érzékelhető, ahol szelídebb lejtőkön, kisebb dombok között a lepusztulás mértéke kisebb volt és a löszlepel foltokban megmaradt.

A kopár gránitfelszíneket fajszegény mészkerülő sziklagyep-foltok és pionír gyepek borítják, állandó elemei a Rumex acetosella, a Hieracium pilosella, gyakori a Jasione montana, Gagea bohemica. Ezeket a szilikát-sziklagyepeket FEKETE (1955) Asplenium septentrionale-Festuca glauca asszociáció-néven tárgyalja, szisztematikus feldolgozásuk a mai napig hiányzik.

A hegység jobb állapotú, fajgazdag sztyepprét-állományai (szüntaxonómiailag nem feldolgozott Festuca rupicola, Stipa pennata, Stipa dasyphylla, Carex humilis stb. gyepek) általában azokon a részterületeken jellemzőbbek, ahol a löszhatás erősebb. Így a Meleg-hegy tömbjében (Géczi-hegy, Új-hegy, Nagylegelő) és délnyugat felé lealacsonyodó dombjain (Sor-hegy, Gádé-hegy, Polák-hegy, sukoró-pákozdi Csúcsos-hegy, Külső-hegy) találhatók; Stipa dasyphylla, Ornithogalum comosum, Crupina vulgaris, Lathyrus sphaericus fajokkal. Szép sztyepprét-foltokat őriznek a székesfehérvári-egység dombjai (Murvás-hegy, Csúcs-hegy), valamint a Nadap-pázmándi-hegysor kvarcit-dombjai (Cseplek-hegy, Zsidó-hegy, nadapi Csúcsos-hegy) is, itt fajgazdag Stipa pulcherrima gyepek is megtalálhatók. A területen fragmentális Carex humilis-gyepfoltokat FEKETE (1955) - ahogy meszes alapkőzeteken - átmenetként jellemzi a zárt sztyepprétek felé. Fekete Gábor szerint ősiségük bizonyítéka az Achillea ochroleuca, lokális karakterfajuk pedig a Spiranthes spiralis. A hegység gránitterületein az 1950-es években tapasztalt állapothoz képest a Carex humilis térfoglalása csökkenhetett (FEKETE ex verb.), részben a cserjésedés, részben ismeretlen okok miatt. Bizonyára talajtani és vízháztartási okokkal magyarázható, hogy a $S$. spiralis a hegység gránitjain - a Tompos-hegy tömbjében napjainkban nem is sztyeppréteken, hanem már inkább a forrásos helyek közelében, üde, cserjésedő gyepfoltokon fordul elő (vö. ILLYÉs \& TóTH 2006). Ellenben napjainkban is sztyeppréteken él a foltokban löszlepellel fedett, keleti kvarcithegyek (Cseplek-hegy, Zsidóhegy, Csekés-hegy) területén. Napjainkban a legjobb állapotú, fajgazdag Carex humilis-gyepek a pázmándi Cseplek-hegy kvarcitjának foltokban lösszel borított tetején és déli lejtőjén találhatók. Talán ezek azok a sztyepprét-foltok, amelyek legjobban emlékeztethetnek az 1950-es években felmért állapothoz. FEKETE (1955) sztyepprétfelvételei és a mai állapotok összehasonlítása más fajok esetén is jelentős - inkább negatív irányú - változásokra mutat rá. Jó példa erre a hegységben jelenleg ritka Pulsatilla grandis visszaszorulása, amely Fekete Gábor tíz sztyepprétfelvételéből még hétben előfordult az 1950-es években! A félszáraz gyepek kifejezetten ritkák a Velencei-hegységben, leginkább a hegyek északi, északkeleti lejtőinek kicsiny gyepfoltjain, felhagyott szőlőkben ismerhetők fel, minden esetben erősen cserjésedő állományaik.

A sztyeppcserjések, sziklai cserjések két tipikus - a sukorói Csúcsos-hegy Rosa spinosissima-s és a nadapi Csúcsos-hegy Cotoneaster integerrimus-os - állományát BöLöNi (2010) említi. A hegységben jóval gyakoribb Cotoneaster niger néhány előfordulási helyén is felismerhetők a sziklai cserjések (pl. Pogány-kő, Hurka-völgy) kisebb-nagyobb foltjai; a Pázmándi-szikláknál, a kőbánya felett mindkét Cotoneaster-faj előfordulásával. Apró sztyeppcserjés foltok a kelet-velencei egység területén szórványosan sokfelé felismerhetők, a legszebb ( $>50 \mathrm{~m}^{2}$ ) Prunus tenella-foltok a nadapi János-hegyen és a pákozd-sukorói Csúcsos-hegy északi, hegylábi részén találhatók. 
Löszpusztagyepek, a hegység peremén, hegylábakon sokfelé felismerhetők. A hegység belső részén a pákozdi és sukorói gránitdombok között benyúló löszös hát belső területein és szélein jellemzőek (Kulcsár-dűlő, Világos, Abajka, Vontató, Sági-hát), ahol a szántóföldi művelésbe vonástól megmenekültek. Szép, cserjésedő löszpusztagyep található a nadapi Csekés-hegy délkeleti lejtőjén. Említést érdemelnek a nadapi Temető-hegy cserjésedő löszgyepjei. Különleges löszpusztagyep állományok találhatók a Lovasberényi-erdő peremvidékén, az északnyugat-délkeleti irányú Tacsika-hegyen és különösen a Kazal-hegyen; utóbbi helyen igen fajgazdag állományokkal, ritka fajok sorával (Brassica elongata, Hypericum elegans, Phelipanche arenaria, Reseda inodora stb.). A Kazal-hegyen fragmentális löszfalnövényzet is felismerhető.

A hegység északi lábának homokpusztagyep-maradványaira (Fumana procumbens, Onosma arenarium, Polygonum arenarium) is FEKETE (1955) hívta fel a figyelmet. Homoki gyepek fragmentális állományai (Bassia laniflora, Medicago monspeliaca, Plantago arenaria) a nyugat-velencei egység dombjai között, hegylábi részein is megjelennek, de az állományok többsége napjainkra leromlott, egyes foltok az akácosítás és a feketefenyvesítés áldozatául estek.

A Velencei-hegység déli lábán, a Velencei-tó partja felé a xerotherm gyep-cserjés élőhelyeket mocsárrétek, szikes rétek váltják fel (Boros 1937, 1954). Ezen az értékes szikes élőhelyen (Sukoró: Kis-dűlő, Lapos-dűlő, Pákozd: Meszegi-alsó-dűlő, Tószéli-mező, Kopolyás) napjainkra nagy területet borítanak idegenhonos fajok (Elaeagnus angustifolia, Celtis occidentalis, Koelreuteria paniculata, Robinia pseudoacacia) uralta, részben spontán erdőfoltok és cserjések. Egész kis területen Molinia caerulea-gyepek is megtalálhatók. A szikes réteken néhány ponton a Galatella cana, Iris spuria, Allium angulosum tömeges állományai élnek. A parti szikes gyepek, mocsarak még napjainkban is számos, növényföldrajzilag fontos fajt őriznek (pl. Achillea asplenifolia, Anacamptis coriophora, Artemisia santonicum, Bassia sedoides, Bupleurum tenuissimum, Camphorosma annua, Carex divisa, Cirsium brachycephalum, Crypsis aculeata, Melilotus dentatus, Schoenoplectus litoralis, S. tabernaemontani, Scorzonera parviflora, Silene multiflora, Suaeda prostrata, Succisa pratensis, Tripolium pannonicum).

\section{A Velencei-hegység Magyarország növényföldrajzi térképén}

A flóra és a vegetáció kiemelt jellemvonásai tükrében felmerül a kérdés, hogy a Velenceihegység növényföldrajzi értelemben egyáltalán a Matricum (ezen belül Veszprimense) részének tekinthető-e, ahogy a korábbi besorolásokban szerepel (KÁRPÁTI 1960, Pócs 1981), vagy a Praematricumhoz (ezen belül Colocense) tartozik?

Vegetációjából hiányzik, a középhegységben, ebben a tengerszint feletti magasságban jellemző zonális vegetációtípus, a cseres-tölgyes. Habár a Vaskapu-hegy hosszan elnyúló keleti, délkeleti platóján vannak cseres-tölgyeshez közel álló állományok, a terület vegetációs szakirodalma nem beszél cseres-tölgyesről (FEKETE 1955, 2010, BöLÖNI 2010, LENDVAI et al. 2014), a száraz termőhelyű, zonálisnak tekinthető tölgyeseket erdőssztyepp-tölgyesként értékelik. A gyertyános-tölgyesek fragmentálisak, extrazonálisak (KEVEY et al. 2014). A terület flórájában is egyértelmű az alföldi-dombvidéki elemek túlsúlya, feltűnő a középhegységi gyakori erdei fajok hiánya is. Ezek a vonások a mezőföldhöz tartozást támogatják. Ugyanakkor mind vegetációjában, mind flórájában előfordulnak olyan elemek, amelyek a táj növényföldrajzi hovatartozását egyértelműen a középhegységi vonulat felé billentik. Ilyen az edafikus sziklai erdőtársulások (mészkerülő-tölgyesek, bokorerdők, szikla- és törmeléklejtő-erdő állományok) előfordulása, amelyek ugyan a Velencei-hegység középhegységünkben unikális geológiai adottságai (gránit, kvarcit) miatt egyediek, de az alföldön teljesen hiányzó vegetációtípusok. A Matricumhoz tartozás fontos támaszai a középhegységi sziklai reliktumok (pl. Sorbus danubialis, Cotoneaster integerrimus, C. niger, Sempervivum matricum, Asplenium septen- 
trionale), a középhegységi sztyeprétek bokorerdők alföldön hiányzó fajai (pl. Gagea bohemica, Genista pilosa, Lathyrus sphaericus, Stipa dasyphylla) is.

Az alföldi és középhegységi hatások keveredése nemcsak a Velencei-hegységben markáns. BARINA (2004) a Dunántúli-középhegység délkeleti peremvidékét és Mezőföld északnyugati peremvidékét egy széles átmeneti, dombvidéki sávként önálló egységként említi. Ebben a sávban található, de Barina térképén is szigetszerűen kimarad belőle a Velenceihegység (vagy legalábbis annak gránit- és kvarcitterülete). A Velencei-hegység növényföldrajzi besorolása tekintetében meglátásom szerint is indokolt a terület Matricumhoz, Veszprimensehez tartozásának fenntartása (KÁRPÁTI 1960, Pócs 1981).

\section{Enumeráció}

Achillea aspleniifolia Vent.: 8677.4 - Lovasberény: Kenderföldi-dűlő, Rovákja-patak; 8676.4 Pákozd: Zsellér-legelő, Császár-víz m.; 8777.3 - Pákozd: Tószéli-mező; Sós-part; 8777.4 Sukoró: Laposi; (FANTA 1902, Boros 1954, FEKETE 1959, UdVARDY \& BÉNYEI-HIMMER 1999).

Achillea nobilis subsp. neilreichii (A. Kern.) Velen.: 8777.1 - Székesfehérvár: Felső-erdő, Kőrakás-h.; Pátka: Király-berek; 8777.2 - Lovasberény: Cser-h.; Técsi-völgy; Sukoró: Géczih.; Kövecses-h.; Meleg-hegy, Sor-h.; Rigó-h.; 8777.3 - Pákozd: Csikmák-h.; Pogány-kő; Nagymező; Kanca-h.; Tompos-h., Zsellér-mező; Pátka: Ignác-forrás feletti d.; Sukoró: Gádé-dúlő; 8777.4 - Sukoró: Gádé-h.; Gyakori, inkább a hegység déli felében, szárazgyepekben, cserjésekben; (KERNER 1871a: „bei Nadáp und auf Quarzitporphyrhügeln längs dem Velenzersee", FEKETE 1955, 1959, UDVARDY \& BÉNYEI-HIMMER 1999).

Achillea ochroleuca Ehrh.: 8776.4 - Székesfehérvár: Csúcs-h; 8777.1 - Pákozd: Külső-e., Pákozdvár; Bodza-v.; Nagy-legelő; 8777.2 - Nadap: Halastói-árok; János-h.; Csúcsos-h.; 8777.3 - Pákozd: Zsellér-legelő; Telkes-mező; Hajdú-temetés; Suhogó; Karácsony-h.; Csikmák-h.; Belső-h.; Kanca-h.; Bogár-halom; Meszegi-felső-dűlő; Meszegi-alsó-dúlő; Sukoró: Mészeg-h.; Gádé-h.; Ördög-kő-h.; Géczi-h.; Gyapjaszsák; Nagy-legelő; Velence: Bence-h.; (FANTA 1902, Boros 1937, 1954, FeKETE 1955, 1959, UdVARdY \& BÉNYEI-HimMER 1999).

Achillea setacea Waldst. \& Kit.: 8777.1 - Székesfehérvár: Kőrakás-h.; Pátka: Király-berek, Kilicsán; Lovasberény: Kazal-h.; Pákozd: Nagy-legelő; Bodza-v. felett; 8777.2 - Sukoró: Öreg-h.; Sorompó-v.; Kövecses-h.; Nadap: János-h.; Pázmánd: Cseplek-h.; 8777.3 Székesfehérvár: Csala-puszta; Pákozd: Hajdú-temetés; Zsellér-legelő; Tompos-h.; KisFecskés-v.; Suhogó; Karácsony-h.; Bella-v., Urasági-Nagy-mező; Csikmák-h.; Pogány-kő; Belső-h.; Kanca-h; Vontató-Sági-hát; Csúcsos-h.; Meszegi-felső-dűlő; Szúnyog-sziget; 8777.4 - Sukoró: Mészeg-h.; Gádé-h.; Ördög-kő-h.; Gyapjaszsák; Géczi-h.; Velence: Bence-h. A hegység teljes területén, szárazgyepekben gyakori, korábban csak BoRos (1954) említette.

Adonis aestivalis L.: 8777.1 - Pátka: Király-berek; Ritka, degradált szárazgyepben.

Adonis flammea Jacq.: 8777.3 - Pákozd: Bogár-halom; Meszegi-felső-dűlő; szántó szélén és degradált szárazgyepben; Herb. Boros Á., 1942, in agris sub monte Mészeg-hegy. MoLnár et al. (2017) Pátka községhatárából, de a hegységen kívülről jelzi.

Adonis vernalis L.: 8677.4 - Lovasberény: Tú-h.; Cser-h.; 8777.1 - Székesfehérvár: Kőrakás-h.; Lovasberény: Kányás-v.; Széles-tető; Bika-v.; Tacsika-h.; Vaskapu-h.; Mogyorós-alj; Szorosv.; Técsi-v.; Pákozd: Pince-d.; Olasz-v.; Külső-erdő; Hurka-v.; 8777.2 - Lovasberény: Hársastető; Nadap: Templom-h.; Temető-hegyi-dúlő; Nyír-h.; Farkas-gödör; Csúcsos-h.; Pázmánd: Cseket-h.; Cseplek-h.; János-tanya; Téglaházi-dűlő; Sukoró: Öreg-h.; 8777.3 - Pákozd: 219,5 m-es d. Hurka-v. felett; Mészeg-h.-Meszegi-alsó-dúlő; Sukoró: Gádé-dűlő; 8777.4 - Sukoró: 
Mészeg-h.; (FAnTA 1902, FeKETE 1955, 1959, UdVARDY \& BÉNYEI-HimMER 1999, LendVAi et al. 2014).

Aegilops cylindrica Host: 8777.2 - Nadap: Csúcsos-h. alja, Csont-rét szántói; Bence-hegy, felhagyott kőbánya; 8777.3 - Sukoró: Csúcsos-h. alja; 8777.4 - Sukoró: Rigó-h., felhagyott kőbánya; Dögállási-legelő; Herb. Boros Á., 1933, inter vineas Velence versus Nadap; (FANTA 1902: Székesfehérvár).

Agropyron cristatum (L.) Gaertn.: 8776.4 - Székesfehérvár: Csala és Kisfalud közötti földút szélén; 8777.1 - Pátka: Király-berek, Kilicsán; Lovasberény: Kazal-h.; 8777.2 - Nadap: János-h.; Pázmánd: Cseplek-h.; Csekés; 8777.3 - Pákozd: Telkes-mező; Hajdú-temetés; Csúcsos-h.; Bogár-halom; Meszegi-alsó-dúlő; 8777.4 - Sukoró: Dögállási-legelő; Gyapjaszsák; Zsellér-Nagy-legelő; Löszön, löszlepellel érintett gyepekben, útszéleken gyakori, inkább a peremeken. Herb. Fanta A., 1882, Fehérvár Szőllőhegy; Boros Á., 1938, Kápolnásnyék; Boros Á., 1933, in collibus Velence versus Nadap; (FANTA 1902, FEKETE 1959, UDVARDY \& BÉNYEI-HIMMER 1999, TAMÁs \& CSONTOS 2003).

Agrostemma githago L.: 8777.1 - Pátka: Sós-ér-dűlő-Varga-h.; Lovasberény: Nadapi-úti-dűlő; 8777.2 - Nadap: Csúcsos-h. alja, Pázmándi-útra-dűlő; Cseket-h.; 8777.3 - Székesfehérvár: Gulyajárás; Pákozd: Bogár-halmi-dűlő; Pottya; Meszegi-felső-dűlő; 8777.4 - Sukoró: Gádédűlő; Országút-alatti-dűlő; Koldus-telek; Szórványosan, útszéleken, szántók szélén; (PINKE at al. 2006).

Aira elegantissima Schur: 8777.1 - Pátka: Király-berek, Kilicsán; 8777.2 - Sukoró: Sorompóv.; Meleg-h.; 8777.3 - Pákozd: Tompos-h.; Zsellér-legelő; Ősi-h.; Pogány-kő; (BoRos 1954).

Ajuga chamaepitys (L.) Schreb.: 8777.1 - Lovasberény: Kazal-h.; Diós; 8777.2 - Pázmánd: Cseplek-h.; Csekés; 8777.3 - Pákozd: Zsellér-legelő; Telkesek; Hajdú-temetés; Karácsony-h.; Meszegi-alsó-dűlő; 8777.4 - Sukoró: Rigó-h.; (PINKE at al. 2006).

Ajuga laxmannii (Murray) Benth.: 8777.2 - Lovasberény: Lovasberényi-erdő, Hársas. Korábban hegység más részein is találták: KERNER 1874b: „auf dem Meleghegy bei Nadap”, FEKETE 1955, 1959: „Sukorói erdő”; „Világosmajor”. LendVAI et al. (2014) szintén a Lovasberényi-erdő területéről jelzi.

Alcea biennis Winterl: 8776.4 - Székesfehérvár: Jancsár, Császár-víz feletti dombok; Pákozd: Mészeg-h., M7 autópálya mellett; Herb. Simonkai L., 1904, Nadap; Filarszky N. \& Kümmerle J. B., 1904, Nadap; Boros Á., 1938, Pázmánd: Zsidó-h.; Boros Á., 1949, Sukoró: Csúcsos-h.

Allium rotundum L.: 8777.1 - Pátka: Király-berek, Kilicsán; 8777.2 - Nadap: Csúcsos-h. alja, Csont-rét szántói; 8777.3 - Pákozd: Bogár-halom; Meszegi-alsó-dűlő; 8777.4 - Sukoró: Rigó-h.; Herb. Boros Á., 1949, Csúcsos-hegy prope Sukoró.

Allium sphaerocephalon L.: Sztyeppréteken a hegység teljes területén elterjedt (FANTA 1902, FEKETE 1955, 1959, UdVARDY \& BÉNYEI-HIMMER 1999, TAMÁs \& CSONTOS 2003).

Alyssum montanum L.: 8777.1 - Pátka: Király-berek, Kilicsán; Sztyeppréteken, igen ritka; (FEKETE 1955, 1959).

Alyssum turkestanicum Regel \& Schmalh.: 8777.3 - Székesfehérvár: Csala-puszta; Pákozd: Telkes-mező; Tompos-h.; Ritka, hegylábi legelőkön, homokos löszös helyeken; Herb. Boros Á., 1933, Nadap; Kárpáti Z., 1933, Sukoró; Boros Á., 1934, Sukoró; Boros Á., 1940, Mészeg-h.; Boros Á., 1944, Kisfalud, Csúcsos-h.; Papp J., 1944, Székesfehérvár, Csúcsos-h. (Boros 1954).

Anacamptis morio (L.) R. M. Bateman, Pridgeon \& M. W. Chase: 8777.1 - Pátka: Király-berek; 8777.2 - Sukoró: Kövecses-h.; Meleg-h.; Nagy-legelő; Új-h.; Nadap: Pap-föld; Pázmánd: Zsidó-h.; Cseplek-h.; 8777.3 - Pákozd: Világos; Vontató-Sági-hát; (MolNÁR 2011a).

Anacamptis pyramidalis (L.) Rich.: 8777.1 - Lovasberény: Fenyves-v.; 8777.3 - Pákozd: Császár-víz és Hajdútemetés között, száraz réten; (MolNÁR 2011c).

Androsace elongata L.: 8777.3 - Pákozd: Ősi-h.; Suhogó; Karácsony-h.; 8777.4 - Sukoró: Rigóh.; Öreg-h. (KERNER 1875: „Meleghegy bei Nadáp”; FANTA 1902; Boros 1937, 1954).). 
Anemone sylvestris L.: 8777.2 - Lovasberény: Lovasberényi-erdő, Hársas-nyiladék; Ritkulóban, korábban több ponton; (FEKETE 1955, 1959, LENDVAI et al. 2014).

Anthemis ruthenica M. Bieb.: 8777.2 - Sukoró: Nagy-legelő; Meleg-h.; Új-h; 8777.3 - Pákozd: Zsellér-legelő; Tompos-h.; Telkes-mező; 8777.4 - Sukoró: Szérűskert; Ördög-kő-h.; Gyapjaszsák.

Artemisia annua L.: 8777.2 - Nadap: Antónia-h.; Sukoró: Gyapjaszsák, Köpüs-árok; Sorompó-völgyi út; Útszéleken, szemétkupacokon.

Artemisia austriaca Jacq.: 8776.4 - Székesfehérvár: Csúcs-h.; Jancsár; (Kisfalud) Murvás-h.; 8777.1 - Pákozd: Bodza-v. felett; Nagy-legelő; 8777.2 - Sukoró: Sor-h.; Nagy-legelő; Melegh.; Sorompó-v.; Kövecses-h.; Géczi-h.; Nadap: János-h.; Halastói-árok; 8777.3 - Pákozd: Zsellér-legelő; Telkes-mező; Hajdú-temetés; Tompos-h.; Ősi-h.; Kis-Fecskés-v.; Suhogó; Karácsony-h.; Urasági-Nagy-mező; Csikmák-h.; Pogány-kő; Belső-h.; Kanca-h.; Vontató; Bella-v.; Külső-h.; Polák-h.; Hurka-v.; Meszegi-felső-dűlő; Meszegi-alsó-dűlő; Tószéli-mező; Szúnyog-sziget; Sukoró: Csúcsos-h.; Gádé-dűlő; 8777.4 - Sukoró: Szérűskert; Mészeg-h.; Csöntör-h.; Öreg-h; Gyapjaszsák; Zsellér-Nagy-legelő; Ördög-kő-h.; Dögállási-legelő; Herb. Tauscher Gy., 1869, Nadap; Boros Á., 1922, Melegh.; Nadap; Jávorka S., 1922, Melegh.; Boros Á., 1933, Velence; Sukoró; Kárpáti Z., 1934, Melegh.; Jávorka S., 1937, Melegh.; Boros Á., 1939, Nagy-sziget; Jávorka S., 1949, Sukoró; Pénzes A., 1949, Nadap; Károlyi Á., 1953, Melegh.; Dudich E., 1955, Nagy-sziget; Jávorka S. \& Csapody V., 1957, Melegh.; Máthé I., 1960, Sukoró; Szollát Gy., 2005, Mészeg-h; (Kitaibel 1816 ap. LőKÖS 2001, KERNER 1871a, Boros 1937, 1954, FEKETE 1955, 1959). A faj velencei-hegységi gyakorisága valószínűleg nem független a terület tájhasználatától, regionális elterjedése szépen kijelöli a hegység déli felének meleg, száraz legelőterületeit. A faj zavarás-, legelés- és taposástűrését a Budai-hegységben (SOMLYAY 2005) és a Tihanyi-félszigeten (BAUER 2014) a található tömeges állományai is megerősítik.

Artemisia pontica L.: 8777.2 - Pázmánd: Csekés; Cseplek-h.; Zsidó-h.; Nadap: Csúcsos-h.; Herb. Tauscher Gy., 1869, Meleghegy pr. Nadap.

Asplenium septentrionale (L.) Hoffm.: 8777.1 - Pákozd: Pákozdvár; Bodza-v.; 8777.2 Sukoró: Lyukas-kő; Pázmánd: Zsidó-h., Pázmándi-sziklák; 8777.2 - Pákozd: Pogány-kő; Pandúr-kő; (Boros 1937, 1954, FEKETE 1955, 1959, TAMÁs \& CSONTOS 2003, TARSOLY 2015: Oroszlán-kő-barlang, Rejtek-barlang, Kőrózsa-álbarlang).

Aster amellus L.: 8777.2 - Nadap: Csúcsos-h.; Cseket-h.; Herb. Tauscher Gy., 1871, Pázmánd; (FEKETE 1955, 1959, ILLYÉs \& BÖLÖNI 2007).

Astragalus asper Jacq.: 8777.1 - Lovasberény: Kánya-v.; 8777.2 - Nadap: János-h.; 8771.3 Pákozd: Világos; Csúcsos-h.-Külső-h.; Sukoró: Csúcsos-h.; Rigó-h.; (FANTA 1902, FEKETE 1955, 1959, UdVARDY \& BÉNYEI-HIMMER 1999).

Astragalus austriacus Jacq.: 8777.1 - Lovasberény: Kazal-h.; 8777.2 - Nadap: Cseket-h.; Pázmánd: Cseplek-h.; 8771.3 - Pákozd: Világos; Meszegi-felső-dűlő; Velence: Bence-h.; 8771.4 - Sukoró: Mészeg-h.; Herb. Barina Z., 2003, Velence: Gurjál (a hegység pereméről); (FANTA 1902: Székesfehérvár, TAMÁs \& CsonTOS 2003).

Bassia Ianiflora (S. G. Gmel.) A. J. Scott: 8777.3 - Pákozd: Tompos-h., Bella-v. (N 47,227793 E 18,52528833ํ); Nagy-Fecskés; Világos.

Bidens frondosus L.: 8676.2 - Székesfehérvár: Pátkai-víztározó partja (N 47,250958 E 18,48731); 8676.2 - Székesfehérvár: Malom-h., Kanális.

Bombycilaena erecta (L.) Smoljan.: 8777.2 - Pázmánd: Cseplek-h.; Herb. Boros Á., 1933, Nadap; Boros Á., 1934, Kövecses-h. Sukoró; (Bonos 1937).

Brassica elongata Ehrh.: 8777.1 - Lovasberény: Kazal-h. (N 47,29753667 E $18,56474333^{\circ}$ ), löszpusztagyepjeiben gyakori.

Bupleurum affine Sadler: 8776.4 - Székesfehérvár (Kisfalud): Murvás-h.; 8777.1 - Pátka: Király-berek, Kilicsán; Lovasberény: Szűzvári-h.; Tacsika-h.; Técsi-v; 8777.2 - Lovasberény: 
Cser-h.; Pázmánd: Zsidó-h.; Nadap: Csúcsos-h.; Temető-hegy-dűlő; János-h.; Halastói-árok; Sukoró: Kövecses-h.; Sor-h.; Nagy-legelő; 8777.3 - Pákozd: Tompos-h.; Vontató; Világos; Meszegi-alsó-dűlő; Sukoró: Csúcsos-h.; Mészeg-h. 8777.4 - Sukoró: Dögállási-legelő; Gyapjaszsák; Herb. Tauscher Gy., 1868, Nadap; Szollát Gy., 2003, Pátka: Varga-hegy; (KerNer 1870b: „Meleghegy bei Nadap”, FEKETE 1955, 1959).

Bupleurum pachnospermum Pančić: 8776.4 - Székesfehérvár: Máriás-h.; 8777.1 Székesfehérvár: Felső-erdő; Kőrakás-h.; Lovasberény: Szűzvári-h.; Kazal-h.; 8777.2 Pázmánd: Zsidó-h; Cseplek-h.; Nadap: Csúcsos-h.; Nadap: János-h.; Bence-h.; Sukoró: Kövecses-h.; Nagy-legelő; 8777.3 - Pákozd: Karácsony-h.; Kanca-h.; Bogár-halom; Kulcsárdűlő; Világos; Külső-h.; Polák-h.; Hurka-v.; Csúcsos-h.; Mészeg-h.; Meszegi-alsó-dűlő; Sukoró: Gádé-dűlő; 8777.4 - Sukoró: Mészeg-h.; Szérűskert; Rigó-h.; Csöntör-h.; Ördög-kőh.; Dögállási-legelő; Gyapjaszsák; Új-h.; Velence: Bence-h.; Gyakori szárazgyepfaj a területen, de inkább a peremeken, szőlőhegyek gyepjeiben jellemzőbb; Herb. Tauscher Gy., 1870, Székesfehérvér; Fekete G., 1953, Pázmánd; Károlyi Á., 1953, Velence; Somlyay L. \& Bauer N., 2010, Pákozdi ingókövek, Urasági-Nagymezö, Sukoró: Géczi-h., Nagy-legelö; (FanTA 1902: "B. gerardi" néven, FEKETE 1955, 1959).

Bupleurum praealtum L.: 8777.2 - Lovasberény: Mária-völgy, Hársas-nyiladék (N

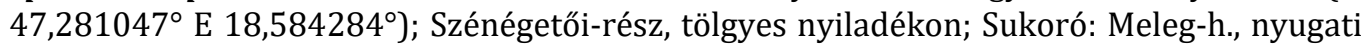
gerinc; 8777.3 - Pákozd: Csúcsos-h.-Külső-h., cserjésben.

Bupleurum rotundifolium L.: 8777.2 - Nadap: Csúcsos-h. (N 47,26785667 E 18,62730833º); Pázmánd: Zsidó-h.; 8777.4 - Velence: Bence-h.; szőlőhegyeken, szántók, utak szélén.

Callitriche palustris L.: 8777.2 - Lovasberény: Szoros-v. feletti háton (N 47,26701667 E 18,58226833); pocsolyás helyen, csertölgy állományban.

Camelina microcarpa Andrz. ex DC.: 8777.3 - Pákozd: Hajdú-temetés; Suhogó; (PINKE at al. 2006).

Campanula rapunculus L.: 8777.1 - Pátka: Király-berek; Sukoró: Sor-h.; 8777.2 - Sukoró: Meleg-h.; Kövecses-h.; Géczi-h.; Nadap: János-h.; Bence-h.; Csúcsos-h.; Pázmánd: Cseplek-h.; 8777.3 - Pákozd: Karácsony-h.; Csikmák-h.; Belső-h.; Kanca-h.; Meszegi-felső-dűlő; Polákh.; Csúcsos-h.; 8777.4 - Sukoró: Gádé-h.; Szérűskert; Velence: Bence-h.; (Boros 1954).

Carduus $\times$ ortocephalus Wallr. (C. acanthoides $\times$ nutans): 8777.2 - Pázmánd: Cseplek-h. (N $47,26594833^{\circ} \mathrm{E} 18,6528^{\circ}$ ), délnyugati lejtőjének sztyepprétjén, a szülőfajok között.

Carex divisa Huds.: 8777.3 - Pákozd: Tószéli-mező; 8777.4 - Sukoró: Lapos-dűlő; szikes rét töredékeken (FANTA 1902, BOROS 1954).

Carex supina Wahlenb.: 8776.4 - Székesfehérvár: Csúcs-h.; Jancsár; Murvás-h.; 8777.1 Pákozd: Hurka-v.-Külső-erdő; 8777.2 - Sukoró: Sukoró: Nagy-legelő; Meleg-h.; Öreg-h.; Sorompó-v.; Kövecses-h.; 8777.3 - Pákozd: Telkes-mező; Ősi-h.; Tompos-h.; Sár-h.; Pogánykő; Csikmák-h.; Sukoró: Gádé-dúlő; 8777.4 - Sukoró: Gyapjaszsák; Új-h.; Herb. Tauscher Gy., 1870, Nadap: Melegh.; Fanta A., 1882, Fehérvár: grániton; Boros Á., 1933, Sukoró; Boros Á., 1934, Kövecses-h.; Kárpáti Z., 1934, Nadap: Melegh.; Boros Á., 1940; Sukoró: Új-h.; (FanTA 1902, BOROS 1937, 1954).

Carthamus lanatus L.: 8777.3 - Pákozd: Telkes-mező; Ősi-h.; Bella-v., Urasági-Nagy-mező; Csikmák-h.; Sár-h.; Pogány-kő; (BARTHA et al. 2015: 8777.3)

Caucalis platycarpos L.: 8777.3 - Pákozd: Mészeg-h. (N 47,217065 E 18,57838167); 8777.4 - Sukoró: Ördög-kő-h.; Velence: Bence-h.; sztyeppréteken, útrézsűben.

Centaurea scabiosa subsp. sadleriana (Janka) Asch. \& Graebn.: 8776.4 - Székesfehérvár: Máriás-h; Malom-h.; 8777.1 - Pátka: Király-berek; Sági-h. Abajka; Pákozd: Világos; Olasz-v.; Lovasberény: Kazal-h.; Nadapi-úti-dűlő; 8777.2 - Lovasberény: Diós; Mária-v.; Pázmánd: Téglaházi-dúlő; Zsidó-h.; Cseplek-h.; Kápolnásnyék: Csekés, Tóth-tanya; Nadap: Cseket-h.; Csúcsos-h.; Halastói-árok; Sukoró: Új-h.; 8777.3 - Pákozd: Meszegi-felső-dűlő; Csúcsos-h.- 
Külső-h.; 8777.3 - Sukoró: Rigó-h.; (FEKETE 1955, 1959, UdVARDY \& BÉNYEI-HimmeR 1999, LENDVAI et al. 2014).

Centunculus minimus L.: 8777.3 - Pákozd: Kis-Fecskés, Tompos-hegy, pocsolyás helyen, Juncus bufonius tömegben (N 47,22105 E 18,52002833).

Cephalanthera damasonium (Mill.) Druce: 8777.1 - Lovasberény: Bika-v.; Kánya-v; Pákozd: Hurka-v.; 8777.2 - Lovasberény: Mária-v.; (BARTHA et al. 2015: 8777.1, 2).

Cephalaria transsylvanica (L.) Roem. \& Schult.: 8777.3 - Pákozd: Mészeg-h., M7 autópálya mellett; 8777.4 - Sukoró: Lapos-dűlő; Kis-dűlő; Csárda-rét; (BARTHA et al. 2015: 8777.4)

Cirsium boujartii (Piller \& Mitterp.) Sch. Bip.: 8777.3 - Pákozd: Tompos-h.; Pogány-kő; Bogárhalmi-dúlő; 8777.4 - Sukoró: Új-h, Zsellér-nagy-legelő; legelőkön, degradált szárazgyepekben; Herb. Károlyi Á., 1953; a faj első velencei-hegységi adatára CsıiKY et al. (2005) hívta fel a figyelmet, de a dolgozat térképén és a flóraatlaszban (BARTHA et al. 2015) nem szerepel megerősített előfordulása a területről.

Cystopteris fragilis (L.) Bernh.: 8777.1 - Lovasberény: Bika-v.; Szoros-v.; 8777.2 Lovasberény: Lovasberényi-erdő, Határ-v.; Meleg-h., Hajagos.; lösz-szurdok szerű erodálódó völgyfők, árnyas erdei útbevágások; (BARTHA et al. 2015: 8777.1, 2).

Convolvulus cantabrica L.: 8776.4 - Székesfehérvár: Csúcs-h.; 8777.1 - Pátka: Király-berek; Lovasberény: Tacsika-h.; Pákozd: Világos; Olasz-v.; 8777.2 - Pázmánd: Zsidó-h.; Cseplek-h.; Nadap: Csúcsos-h.; Sukoró: Új-h.; Kövecses-h.; Rókalyukas-v.; 8777.3 - Pákozd: Zsellérlegelő; Telkes-mező; Ősi-h.; Kis-Fecskés-v.; Külső-h.; 8777.4 - Sukoró: Rigó-h.; Velence: Bence-h.; Herb. Boros Á., 1938, Pázmánd: Zsidó-h.; Boros Á., 1939, Pákozd: Nagy-sziget; Károlyi Á., 1953, Pákozd; (Fanta 1902, Boros 1937, 1954, FeKETE 1955, 1959, UdVARDY \& BÉNYEI-HIMMER 1999, TAMÁS \& CSONTOS 2003).

Cotoneaster integerrimus Medik.: 8777.2 - Nadap: Csúcsos-h.; Pázmánd: Zsidó-h.; 8777.3 Pákozd: Mészeg-h.; 8777.4 - Sukoró: Köpüs-árok; A Cotoneaster-fajokat Somlyay Lajossal közösen térképeztük. (BöLÖNI 1999, 2010, TAMÁs \& CSONTOS 2002, BARTHA et al. 2015: 8777.2, 8777.3).

Cotoneaster niger (Fr.) Fr.: 8777.1 - Pákozd: Bodza-v.; 8777.2 -Sukoró: Meleg-h.; Kövecsesh.; Nadap: Csúcsos-h.; Pázmánd: Zsidó-h.; 8777.3 -Pákozd: Pogány-kő; Pandúr-kő; Külső-h.; Hurka-v.; 8777.4 -Sukoró: Éva-forrás völgye; (BöLÖNI 1999, UdVARDY \& BÉNYEI-HIMMER 1999, BARTHA et al. 2015: 8777.1, 8777.2, 8777.3, 8777.4).

Crepis pulchra L.: 8777.1 - Lovasberény: Alsó-Cser-h., Diós (N 47,29603ํ E 18,58194); 8777.2 - Lovasberény: Cser-h.; Lovasberényi-erdő, Andor-nyiladék; Antónia-h., Mélyút-v.; Nadap: Csúcsos-h.; 8777.2 - Pákozd: Tószéli-mező.

Crupina vulgaris Cass.: 8777.2 - Sukoró: Kövecses-h., Rókalyukas-völgy; Nadap: Csúcsos-h.; Herb. Tauscher Gy., 1873, Nadap: Melegh.

Cyanus triumfettii (All.) Á. Löve \& D. Löve: 8777.1 - Lovasberény: Szúzvári-h.; Bika-v.; Tacsika-h.; 8777.2 - Nadap: Antónia-h.; Sukoró: Sorompó-v.; Sukoró: Öreg-h.; 8777.3 Pákozd: Pandúr-kő; Külső-h.; Polák-h.; (UdVARDY \& BÉNYEI-HIMMER 1999).

Cytisus ratisbonensis Schaeff.: 8777.2 - Lovasberény: Lovasberényi-erdő, Hársas-nyiladék; Sukoró: Meleg-h.; 8777.3 - Pákozd: Urasági-Nagy-mező; Csikmák-h.; (LENDVAI et al. 2014, BARTHA et al. 2015: 8777.1).

Dictamnus albus L.: 8777.1 - Lovasberény: Tacsika-h.; Vizesvölgyi-nyiladék; Bika-völgyi-hát; Vaskapu-h., Lászlóházi- nyiladék; Szoros-v.; Rózsalátó; 8777.2 - Lovasberény: Hársas-tető; Szénégetői-rész; Cser-h.; Farkas-gödör; Nadap: Antónia-h.; Templom-h.; Nyír-h.; Csúcsos-h.; Sukoró: Meleg-h.; Rókalyukas-v.; Sorompó-v.; Öreg-h.; 8777.4 - Sukoró: Gádé-h.; Regionális elterjedése a hegység északeleti, keleti felében koncentrálódik; (FEKETE 1955, 1959, FEKETE \& JAKUCS 1957, UDVARDY \& BÉNYEI-HIMMER 1999, ILLYÉs \& BöLÖNI 2007, LENDVAI et al. 2014).

Doronicum hungaricum Rchb. f.: 8777.1 - Pátka: Sági-h.; Lovasberény: Fenyves-v.; Szélestető; Lászlóházi-erdő; Pákozd: Kányás; 8777.2 - Lovasberény: Rózsalátó-nyiladék; Mária-v.; 
Hársas-tető; Meleg-h.; Antónia-h.; Nadap: Bük-hang; Mély-út; Templom-h.; Csúcsos-h.; Herb. Boros Á., 1922, Nadap; Boros Á., 1922, Kirchenberg és Cserh.; Soó R., 1922, Nadap: Melegh.; Jávorka S., 1922, Sukoró: Melegh.; Jávorka S., 1927, Nadap: Melegh.; Kárpáti Z., 1934, Melegh.; Boros Á., 1934, Melegh.; Jávorka S., 1949, Sukoró; (KERNER 1871b: „Meleghegy bei Nadáp", BoRos 1937, FEKETE 1955, 1959, KEVEY et al. 2014 LENDVAl et al. 2014).

Draba nemorosa L.: 8776.4 - Székesfehérvár: Malom-h., legeltetett parlagon; 8777.1 Pákozd: Kányás, szárazgyepben (N 47,26313333은 Lovasberény: Lovasberényi-e., a Kastély-nyiladékon, murvás úton.

Drabella muralis (L.) Fourr.: 8777.1 - Pákozd: Kányás; Sukoró: Sor-h.; 8777.2 - Nadap: Antónia-h.; Csúcsos-h.; Sukoró: Új-h.; Kövecses-h; Nagy-legelő; Meleg-h.; 8777.3 - Pákozd: Tompos-h; Sár-h.; Pogány-kő; 8777.4 - Sukoró: Szérúskert; Mészeg-h.; Velence: Bence-h.; Herb. Kárpáti Z., 1934, Nadap: Melegh.; Boros Á., 1934, Sukoró: Kövecses-h.; Bánó L., 1951, Melegh.; (BoRos 1937).

Dryopteris carthusiana (Vill.) H. P. Fuchs: 8777.2 - Pázmánd: Zsidó-h., Pázmándi-sziklák, az északkeleti sziklás lejtőn, sziklahasadékban (N 47,27493167 18,66244333º).

Echium italicum L. 8776.4 - Székesfehérvár: Jancsár; Murvás-h.; Császár-víz-menti legelők; Csalai-erdő széle, Csalapuszta; 8777.2 - Pázmánd: Cseplek-h.; Nadap: János-h.; Sukoró: Kövecses-h.; Nagy-legelő; 8777.3 - Pákozd: Zsellér-legelő; Tompos-h.; Ősi-h.; SuhogóKarácsony-h.; Urasági-Nagy-mező; Csikmák-h.; Bogár-halmi-dűlő; Mészeg-h.; 8777.4 Sukoró: Ördög-kő-h.; Gyapjaszsák; Géczi-h.; Dögállási-legelő; (FANTA 1902, BoROS 1954 UDVARDY \& BÉNYEI-HIMMER 1999).

Eleocharis acicularis (L.) Roem. et Schult.: 8777.1 - Székesfehérvár (Kisfalud): Murvás-h., felhagyott bányagödör, vízállás szélén (N 47,20664667º E 18,49942º).

Epilobium dodonaei Vill.: 8777.3 - Pákozd: kőbánya, Heim-tanya közelében; 8777.2 Pázmánd: Zsidó-h., kőbánya; (MolnáR et al. 2000, IlLYÉS \& TóTH 2005, BARTHA et al. 2015: AFH8777.2).

Epipactis microphylla (Ehrh.) Sw.: 8777.1 - Pátka: Sági-h.; 8777.2 - Lovasberény: Lovasberényi-erdő, Hársas-nyiladék; (MOLNÁR 2011b, LENDVAI et al. 2014).

Epipactis voethi Robatsch: 8777.1 - Pákozd: Hurka-v.; Bodza-v.; üde gyertyános-tölgyesben, a patak közelében; (MÉsZÁros et al. 2011).

Eragrostis cilianensis (All.) F.C.Hubbard: 8777.2 - Nadap: János-h.; 8777.3 - Pákozd: Hajdútemetés; Telkes-mező; Ősi-h.; Karácsony-h.; 8777.4 - Velence: Bence-h.; Herb. Károlyi Á., 1950, secus vias pr. pag Pákozd.

Eragrostis pilosa (L.) P. Beauv.: 8777.2 - Nadap: János-h. gerincén, a Bence-h. felé (N 47,250165 E 18,62126167º); Sukoró: Kövecses-h.; 8777.3 - Pákozd: Tompos-h.; Zsellérlegelő; 8777.4 - Velence: Bence-h.; gránitfelszínek taposott, bolygatott gyepjeiben.

Euphorbia × angustifrons Borb.: 8777.2 - Pázmánd: Zsidó-h.; 8777.3 - Pákozd: Tompos-h.; Pandúr-kő legelőin; 8777.4 - Sukoró: Csúcsos-h.; Gádé-dűlő; Rigó-h.; szőlőhegyi szárazgyep-maradványokon a szűlőfajok között; Herb. Boros Á., 1939, Sár-hegy pr. Pákozd.

Euphorbia exigua L.: 8777.2 - Pázmánd: Csekés, szőlőhegyi gyomtársulásban; 8777.3 Pákozd: Bogár-halmi-dűlő (N 47,2188933ํ E 18,5577667º).

Euphorbia lathyris L.: 8777.1 - Lovasberény: Nadapi-úti-dűlő; 8777.4 - Sukoró: Tiborc-v.; útszélen.

Euphorbia maculata L.: 8777.2 - Pázmánd: Csekés, szőlőhegyi gyomtársulásban (N $\left.47,26364667^{\circ} \mathrm{E} 18,66227833^{\circ}\right)$.

Euphorbia salicifolia Host: 8777.1 - Lovasberény: Vaskapu-h.; 8777.2 - Lovasberény: Szorosv.; Antónia-h.; cseres állományokban, helyenként tömegesen; (LENDVAI et al. 2014).

Euphorbia taurinensis All.: 8777.4 - Velence: Bence-h. (N 47,24701333ํㅡ E 18,62406833), útrézsűben. 
Filago minima (Sm.) Pers.: 8777.3 - Pákozd: Ősi-h.; Telkes-mező; Zsellér-legelő; Tompos-h., Nagy-Fecskés; Kis-Fecskés-v. (N 47,22105333 E 18,52001833²), Pogány-kő.

Fragaria moschata Duchense: 8777.2 - Sukoró: Meleg-h., száraz tölgyesben; (FEKETE 1955, 1959).

Fumaria officinalis L.: 8776.4 - Székesfehérvár (Kisfalud): Murvás-h. (N 47,20862833 E 18,49626667º); 8777.3 - Pákozd: Karácsony-h.; Sukoró: Gádé-dűlő; 8777.4 - Sukoró: Rigóh.; Szérűskert, Iharos; ritka, szárazgyepek, szőlőhegyi rézsűk.

Gagea bohemica (Zauschn.) Schult. \& Schult. f.: 8776.4 - Székesfehérvár: Jancsár; 8777.1 Pátka: Király-berek, Kilicsán; 8777.2 - Nadap: János-h., szárazgyepekben a platón, valamint a szintezési alappontok körüli sziklákon; Pázmánd: Zsidó-h.; 8777.3 - Pákozd: Tompos-h.; Kis-Fecskés-v.; Csikmák-h.; Belső-h., Kis-Cipó-dűlő; Pogány-kő, Pákozdi-ingókövek, Kocka; Pandúr-kő; Hurka-völgy; Külső-erdő, Külső-h.; Polák-h.; Csúcsos-h.; Mészeg-h.; Szúnyogsziget (!), a Halászcsárda melletti kis szárazgyep-folton; 8777.3 - Sukoró: Mészeg-h.; Sor-h.; Meleg-h.; Kövecses-h.; Csöntör-h.; Gádé-h.; Sorompó-v., (sok lelőhelyen Somlyay Lajossal térképeztük); Herb. Vajda L., 1934, Melegh.; Boros Á., 1938, Tompos-h.; Boros Á., 1939, Hurka-v.; Boros Á., 1950, Nadap: Antónia-h.; Barina Z., 2003, Székesfehérvár: Jancsár (BoRos 1954, RIEZING 2002, BARINA 2008).

Gagea pusilla (F. W. Schmidt) Sweet.: 8677.4 - Lovasberény: Tü-h.; 8777.1 - Lovasberény: Szűzvári-h.; Kánya-v.; Tacsika-h; Erdőalja-dűlő; Kazal-h.; 8777.2 - Vereb: Istenkas; Pázmánd: Tanyai-dűlő; Téglaházi-dűlő; Zsidó-h.; Sukoró: Kövecses-h.; Rókalyukas-v.; Meleg-h.; Nagy-legelő; Sor-h.; 8777.3 - Székesfehérvár: Csalai-e.; Pákozd: Ősi-h.; Belső-h.; Pogány-kő; Pandúr-kő; Csúcsos-h.; Hurka-völgyi-plató; Mészeg-h.; Meszegi-alsó-dűlő; Herb. Boros Á., 1938, Tomposh.; (FANTA 1902: Székesfehérvár).

Galanthus nivalis L. 8777.1 - Pákozd: Hurka-v.; Bodza-v.; 8777.2 - Lovasberény: Hársas-v.; Mária-v.; 8777.3 - Pákozd: Hurka-v. alsó szakaszán; Külső-h., északi, sziklás lejtőjén; 8777.4 - Velence: Temető erdős részén (szubspont.?); (KevEY et al. 2014).

Galium palustre subsp. elongatum (C. Presl) Lange: 8777.3 - Pákozd: Lapos-V., Kerektóilapos, égeres-mocsaras helyen (N 47,216015 $\mathrm{E}$ 18,57233667\%); (FANTA 1902: Székesfehérvár, "rétek").

Gentiana cruciata L.: 8777.2 - Nadap: Bence-hegy, az északi lejtő cserjésedő félszárazgyepjeiben; Nadap: Csúcsos-hegy-alja, Magas-dűlő; (ILLYÉs \& BÖLÖNI 2007: "nadapi Csúcsos-hegy").

Geranium divaricatum Ehrh.: 8777.1 - Pákozd: Külső-e.; 8777.2 - Nadap: Csúcsos-h; 8777.3 Pákozd: Pandúr-kő; Xerotherm cserjésekben, erdőszéleken, a hegységben szórványos; Herb. Jávorka S., 1922, Melegh. pr. p. Sukoró; (KeRner 1868: „Lovas Berény”).

Globularia bisnagarica L.: 8777.2 - Nadap: Csúcsos-h; Pázmánd: Zsidó-h.; Cseplek-h; 8777.4 Sukoró: Mészeg-h.; Ritka a hegységben, sztyeppréteken; Herb. Tauscher Gy., 1871, Nadap, Melegh.; Boros Á., 1934, Hurka-v.; (FEKETE 1955, 1959, ILlYÉs \& BÖLÖNI 2007).

Gypsophila muralis L.: 8777.1 - Pákozd: Angelika-forrás feletti gyepekben; 8777.2 - Sukoró: Nagy-legelő; Nadap: Antónia-h., felhagyott kőbánya; 8777.3 - Pákozd: Zsellér-mező; Bellav; Pákozdi ingókövek legelője (N 47,23173833 E 18,53714833º).

Helichrysum arenarium (L.) Moench: 8777.1 - Pátka: Király-berek; 8777.2 - Sukoró: Új-h.; Nagy-legelő; 8777.3 - Sukoró: Gádé-h.; Gádé-dűlő; visszaszorulóban. Herb. Filarszky N. et Kümmerle J. B., 1904, Melegh.; Simonkai L., 1904, Melegh., Károlyi Á., 1953, Pákozd; (Boros 1954, FEKETE 1955, 1959).

Helictochloa adsurgens (Simonk.) Romero Zarco: 8776.4 - Székesfehérvár: Jancsár; 8777.1 Székesfehérvár: Kőrakás-h.; Pátka: Király-berek; Lovasberény: Vaskapu-h.; Pákozd: Bodzav. felett; 8777.2 - Sukoró: Sor-h.; Nagy-legelő; Meleg-h.; Új-h.; Nadap: János-h.; Csúcsos-h.; Cseket-h.; Pázmánd: Cseplek-h.; Zsidó-h.; 8777.3 - Sukoró: Gádé-h.; 8777.4 - Velence: 
Bence-h.; Sztyepprét jellegú gyepekben, xerotherm cserjésekben gyakori; (BoRos 1954, FEKETE 1955).

Herniaria incana Lam.: 8777.2 - Nadap: János-h.; Szintezési ősjegy emlékmű feletti gyepben; 8777.3 - Pákozd: Ősi-h.; Karácsony-h.; Vontató; Mészeg-h., Meszegi-alsó-dűlő; Sukoró: Gádé-dűlő; 8777.4 - Sukoró: Mészeg-h.; Szérűskert; Dögállási-legelő; Gyapjaszsák; a Velencei-hegység déli, xerotherm élőhelyekben gazdag vonulatain, szórványos, a keleti kvarcithegyeken hiányzik. Herb. Boros Á., 1933, Sukoró; Boros Á., 1934, Kövecses-h., Boros Á., 1939, Mészeg-h., Boros Á., 1939, Sár-h., Walger R., 1939, Mészeg-h., Boros Á., 1942, Dögállásil.; Boros Á., 1944, Tompos-h.; Boros Á., 1949, Mészeg-h.; (FANTA 1902, Boros 1937, 1954, FEKETE 1955, 1959).

Hesperis tristis L.: 8777.1 - Pákozd: Bodza-v. feletti plató; 8777.2 - Sukoró: Sor-h.; Nagylegelő; Nadap: Csúcsos-h.; 8777.3 - Pákozd: Zsellér-legelő; Csikmák-h.; Kanca-h.; Meszegifelső-dúlő; 8777.4 - Pákozd: Lapos-dűlő; Sukoró: Mészeg-h.; Velence: Bence-h.; zárt sztyeppréteken, szórványosan; Herb. Jávorka S., 1927, Nadap: Csúcsos-h; Kárpáti Z., 1934, Melegh.; (UdVARDY \& BÉNYEI-HIMMER 1999).

Hieracium maculatum Schrank: 8777.2 - Nadap: Antónia-h.; Lovasberény: Hajagos; Sukoró: Meleg-h.; mészkerülő-tölgyes foltokon; (FEKETE 1955).

Hippocrepis comosa L.: 8777.2 - Pázmánd: Zsidó-h.; Cseplek-h.; Nadap: Bence-h., Páskom; 8777.4 - Sukoró: Rigó-h.; Herb. Andreánszky G., 1937, Lovasberény, Meleg-h.; Pénzes A., 1962, Nadap: Bánya-h.; (FANTA 1902, LENDVAI et al. 2014).

Hypericum elegans Willd.: 8777.1 - Lovasberény: Szűzvári-h.; Kánya-v.; Tacsika-h.; Kazal-h. (erős populáció, N 47,29738833 E 18,56401167); 8777.2 - Pázmánd: Cseplek-h. (N 47,26594667 E 18,652945); 8777.3 - Pákozd: Telkes-mező.

Inula germanica L.: 8777.1 - Lovasberény: Kazal-h.; Técsi-v; Pákozd: Kányás; Pákozdvár, Hurka-v; Bodza-v.; 8777.2 - Lovasberény: Mária-v.; Szénégetői-rész; Hársas-nyiladék; Nadap: Temető-hegy-dúlő; Templom-h.; Csúcsos-h.; 8777.3 - Pákozd: Hajdú-temetés; Belső-h.; Kanca-h.; Vontató; Külső-h.; Csúcsos-h.; Polák-h.; Hurka-v. plató; Sukoró: Csúcsosh.; Gádé-h.; Gádé-dűlő; 8777.4 - Sukoró: Rigó-h.; a Velencei-hegységben szórványos, de előfordulása a Sukoró és Pákozd közötti löszös sáv térségében és a Lovasberényi-erdő peremterületein koncentrálódik. Herb. Tauscher Gy., 1875, Sukoró; Tauscher Gy., 1908, Nadap; Boros Á., 1937, Mária-v.; Jávorka S., 1937, Vaskapu; Polgár S., 1937, Lovasberény; Boros Á., 1949, Csöntör-h.; (FANTA 1902, BoRos 1954, TAMÁs \& Csontos 2003, Barina 2008, LENDVAI et al. 2014).

Iris graminea L.: 8777.2 - Lovasberény: Lovasberényi-e, Mária-v. felső szakasza melletti hátakon, mintegy fél négyzetkilométernyi területen; (FEKETE 1954, 1955, 1959, KEvEy et al. 2014, LENDVAI et al. 2014).

Iris pumila L.: 8777.1 - Pátka: Király-berek, Kilicsán; Lovasberény: Kazal-h.; Pákozd: Pákozdvár, Bodza-v.;, Angelika-forrás feletti cserjésedő sztyepprétek; 8777.2 - Sukoró: Nagy-legelő; Nadap: Csúcsos-h.; 8777.3 - Pákozd: Hajdú-temetés; Telkes-mező; Ősi-h.; Tompos-h.; Pandúr-kő; Kanca-h; Abajka; Vontató; Külső-h.; Csúcsos-h.; Hurka-v; Meszegifelső-dűlő; Meszegi-alsó-dűlő; 8777.4 - Sukoró: Mészeg-h. (KerNER 1877: „Meleghegy bei Nadáp", FEKETE 1955, 1959, MolNár et al. 2017).

Jovibarba globifera (L.) J. Parn. subsp. hirta (L.) J. Parn.: 8777.3 - „Above Pákozd, in the Velence Mountains" (UDVARDY \& BÉNYEI-HIMMER 1999); Hurka-völgy (RIEZING 2002).

Juncus tenuis Willd.: 8777.3 - Pákozd: Pákozd: Lapos-dűlő; Kanca-h. és Belső-erdő között, nedves erdei utakon ( $\left.\mathrm{N} 47,23689667^{\circ} \mathrm{E} 18,55036833^{\circ}\right)$.

Jurinea mollis (L.) Rchb.: 8777.1 - Pákozd: Olasz-v.; Lovasberény: Kazal-h.; 8777.3 - Pákozd: Világos; löszgyepekben (UdVARDY \& BÉNYEI-HIMMER 1999).

Kickxia elatine (L.) Dumort: 8777.4 - Sukoró: Lapos-dűlő, szántón (N 47,21972167 E $\left.18,59063^{\circ}\right)$. 
Lactuca viminea (L.) J. Presl \& C. Presl: 8777.3 - Pákozd: Karácsony-h.; Csúcsos-h.; Mészegh.; 8777.4 - Sukoró: Csöntör-h.; Géczi-h.; Velence: Bence-h.; (N 47,24821667 E $18,62476333^{\circ}$ ).

Lathyrus hirsutus L.: 8777.1 - Pátka: Sági-v.; Király-berek; Varga-h.; gyomos, üdébb gyepekben.

Lathyrus sphaericus Retz.: 8777.2 - Sukoró: Kövecses-h.; Sorompó-v.; Nadap: Csúcsos-h.; 8777.3 - Sukoró: Gádé-dűlő; 8777.4 - Sukoró: Géczi-h.; Új-h.; Herb. Degen Á., 1896., Nadap Meleghegy; Kárpáti Z., 1933, Melegh.; Boros Á., 1933, Nadap; Boros Á., 1934, Sukoró; Pénzes A., 1962, Nadap; (KÁRPÁTI 1934, CSIKY 2006).

Lepidium densiflorum Schrad.: 8777.4 - Sukoró: Csöntör-hegy, Haraszt utca, útszéli mezsgyén ( $\left.\mathrm{N} 47,24877833^{\circ} \mathrm{E} 18,58813667^{\circ}\right)$.

Lilium martagon L.: 8777.2 - Lovasberény: Mária-v.; Nadap: Bükk-hang; Antónia-h.; KEVEY et al. (2014), KeveY (2015) a hegységre új fajként közli, de valójában 1869 óta ismert a hegységből. Herb. Tauscher Gy., 1869.08.04., Cott. Albensi. E umbrosi montanis prope Nadap; Bauer N., 2014, Lovasberény: Mária-völgy.

Linaria biebersteinii Besser: 8777.2 - Nadap: Temető-h.; Csúcsos-h.; 8777.3 - Pákozd: Csúcsos-h.; Külső-h.; Polák-h; löszös szárazgyepekben, ritka; Herb. Molnár Cs. et Csathó A. I., 2005, Nadap: Vaskapu-h.

Linum hirsutum L.: 8777.1 - Lovasberény: Kazal-h.; Nadapi-útra-dűlő; Alsó-Cser-h.; 8777.2 Nadap: Cseket-h.; Pázmánd: Cseplek-h.; (Boros 1954, MolnÁr et al. 2017).

Linum tenuifolium L.: 8777.1 - Pátka: Sági-h.; Lovasberény: Fenyves-v.; Szűzvári-h.; Szélestető; Bika-v.; 8777.2 - Nadap: Csúcsos-h; Cseket-h.; Pázmánd: Cibulka-patak menti szárazgyepek; (FEKETE 1955, 1959).

Lipandra polysperma (L.) S. Fuentes \& al.: 8777.1 - Székesfehérvár (Kisfalud): Murvás-h. keleti lábán, felhagyott bányagödör, árnyas, üde termőhelyén ( $\mathrm{N} 47,207295^{\circ} \mathrm{E}$ $18,49892667^{\circ}$ ).

Lythrum portula (L.) D. A. Webb: 8777.3 - Pákozd: Tompos-h., a Nagy-Fecskés völgyfője feletti platón, lefolyástalan mélyedésben, üde, pionír gyepben; (Nadapnál KITAIBEL 1816 ap. LőKÖs 2001).

Lythrum virgatum L.: 8777.3 - Pákozd: Zsellér-legelő, Császár-víz menti réteken; a Velenceitavat kísérő parti szikes gyepekben gyakori. (FEKETE 1954, 1959).

Marrubium remotum Kit. (Marrubium × paniculatum Desr.): 8776.4 - Székesfehérvár: Császár-víz menti száraz legelőkön, Marrubium peregrinum tömegben; 8777.3 - Pákozd: Bella-v., Kalmár büfé közelében, xerotherm útszéli gyepben (BoRos 1973: Nadap, Csúcsoshegyen, 1938.06.27-én).

Medicago monspeliaca (L.) Trautv.: 8776.4 - Székesfehérvár: Csúcs-h.; 8777.3 - Pákozd: Zsellér-mező, Bella-v.; 8777.4 - Sukoró: Szérűskert; Rigó-h.; Ördög-kő-h.; Dögállási-legelő; Herb. Boros Á., 1933, Nadap; Boros Á. 1934 Sukoró; Kárpáti Z., 1934, Nadap; (Boros 1937, 1954, FEKETE 1955, 1959).

Melilotus dentatus (Waldst. \& Kit.) Pers.: 8777.3 - Pákozd: Kerek-tói-lapos; 8777.4 - Sukoró: Óriásnád; part menti nádasok, szikesedő rétek.

Minuartia glomerata (M. Bieb.) Degen: 8777.4 - Sukoró: Rigó-hegy, felhagyott kőbánya udvarán; FANTA (1902) jelzi elsőként (Székesfehérvár, „gránittalajról”) a Velenceihegységből.

Minuartia setacea (Thuill.) Hayek: 8777.1 - Pátka: Király-berek, Kilicsán, köves sztyeppréten (N 47,25411667 E 18,52004667º).

Minuartia viscosa (Schreb.) Schinz \& Thell.: 8777.2 Pázmánd: Cseplek-h.; Zsidó-h.; Nadap: János-h.; 8777.3 - Pákozd: Hajdú-temetés; jelenleg igen ritka. Herb. Boros Á., 1933, Nadap; Boros Á., 1933, Sukoró; Pénzes A., 1933, Melegh; Boros Á., 1934, Kövecses-h.; Kárpáti Z., 1934, 
Melegh.; Boros Á., 1937, Melegh.; Boros Á., 1939, Sár-h., Pogány-kö; Boros Á., 1944, Tomposh.; (BoROs 1937).

Myosurus minimus L.: 8777.1 - Székesfehérvár (Kisfalud): Murvás-h. keleti lábán, felhagyott bányagödör, vízállás szélén (N 47,20664667º E 18,49942); (FANTA 1902, BOROS 1937, 1954, FEKETE 1959).

Nardus stricta L.: 8777.3 - Pákozd: Tompos-h., nedves mélyedéseiben üde gyepfoltokon, két ponton, ahol már Boros Ádám is találta. Herb. Boros Á., 1944, ad fontem rivi Bella-patak, in monte Tompos-h; (BoRos 1949, 1954).

Nepeta nuda L. subsp. nuda: 8777.1 - Lovasberény: Técsi-v (N 47,28031333 E 18,58153167º); 8777.2 - Vereb: Istenkas; Lovasberény: Antónia-h.; Pázmánd: Téglaházidúlő; János-tanya.

Odontites luteus (L.) Clairv.: 8777.1 - Lovasberény: Kazal-h.; 8777.2 - Nadap: Csúcsos-h; Cseket-h.; János-h.; Pázmánd: Cseplek-h.; 8777.3 - Pákozd: Csúcsos-h.; Meszegi-alsó-dűlő; Sukoró: Gádé-dűlő; Gyapjaszsák; Ördög-kő-h.; Velence: Bence-h.; (BARTHA et al. 2015: 8777.1, 2, 3).

Onobrychis arenaria (Kit.) DC.: 8777.2 - Nadap: Cseket-h., cserjésedő sztyeppréten; Herb. Boros Á., 1938, Pázmánd: Cseket-hegy.

Ononis pusilla L.: 8777.2 - Nadap: Csúcsos-h.; Pázmánd: Cseplek-h.; 8777.3 - Pákozd: Külsőh.; a hegység keleti felében (a Hurka-völgytől keletre), sztyeppréteken, nagyon ritka; (FEKETE 1955).

Orchis purpurea Huds.: 8777.1 - Pátka: Sági-h.; Lovasberény: Széles-tető; Bika-v.; Alsó-Cserh.; Pákozd: Kányás; 8777.2 - Vereb: Istenkas; Nadap: Csúcsos-h.; Cseket-h.; Meleg-h.; Papföld; Sukoró: Új-h.; (ILLYÉs \& BöLÖNI 2007, LENDVAI et al. 2014).

Orlaya grandiflora (L.) Hoffm.: 8777.1 - Lovasberény: Tacsika-h. gerincén, löszös sztyeppréten, erdőszegélyen ( $\left.\mathrm{N} 47,2780123^{\circ} \mathrm{E} 18,5490474^{\circ}\right)$.

Ornithogalum comosum L.: 8777.2 - Pázmánd: Zsidó-h.; Nadap: János-h.; Halastói-árok; Sukoró: Új-h.; Kövecses-h.; Meleg-h.; Nagy-legelő, Sor-h.; 8777.4 - Sukoró: Ördög-kő-h.; Gyapjaszsák; Géczi-h; Velence: Bence-h.; jó állapotú löszhatású sztyeppréteken; Herb. Jávorka S., 1949, Sukoró.

Ornithogalum refractum Kit. ex Schltdl.: 8777.2 - Pázmánd: Temető, sírok között, bolygatott folton; (MoLNÁR et al. 2018).

Orobanche alba subsp. major (Celak.) Zázv.: 8777.1 - Lovasberény: Kazal-h., Salvia nemorosa-n, löszgyepben (vö. BARINA 2009).

Oxytropis pilosa (L.) DC.: 8777.1 - Pákozd: Világos; Olasz-v.; 8777.2 - Pákozd: Cseplek-h.; 8777.3 - Pákozd: Külső-h.; Csúcsos-h.; Sukoró: Csúcsos-h. alja; 8777.4 - Rigó-h., kőbánya; Kis-dűlő, a Velencei-tó partján, szárazgyepben; (UDVARDY \& BÉNYEI-HIMMER 1999: Sukoró: Rigó-h.)

Peucedanum arenarium Waldst. \& Kit.: 8777.1 - Lovasberény: Kazal-h.; 8777.2 Lovasberény: Técsi-v.; Mária-v., Hársas-nyiladék; 8777.3 - Sukoró: Csúcsos-h.; 8777.3 Sukoró: Csöntör-h.; Herb. Fekete G., 1957, Lovasberényi országút, Vadászkastély közelében; (FEKETE 1954, 1959).

Phelipanche arenaria (Borkh.) Pomel: 8777.1 - Lovasberény: Kazal-h., löszpusztagyepben, Artemisia campestris-en; (Boros 1973: Nadap, Csúcsos-hegyen, 1938.06.27-én).

Phelipanche purpurea (Jacq.) Soják: 8777.2 - Sukoró: Nagy-legelő, Achillea neilreichii-n; (FEKETE 1955); a hegységen kívül, a Dinnyési-fertőn is előkerült: 8877.1 - Gárdony (Dinnyés): Dinnyési-puszta, szikes legelőgyepben, Achillea collina-n.

Phleum nodosum L. (syn. Phleum bertolonii DC.): Lovasberény: Szoros-völgy, erdőszéli mezofil gyepben (N 47,277635 ${ }^{\circ}$ 18,56773833).

Phlomis tuberosa L.: 8777.1 - Pátka: Király-berek; Lovasberény: Bika-v.; 8777.2 - Nadap: Templom-h.; Csúcsos-h.; Cseket-h.; (FEKETE 1955, IllYÉs \& BöLÖNI 2007, LENDVAI et al. 2014). 
Plantago arenaria Waldst. \& Kit.: 8777.3 - Pákozd: Zsellér-legelő; Tompos-h.; Zsellér-mezőalja, Bella-v.; Székesfehérvár: Csala-puszta; legelőkön, homokos foltokon; (FANTA 1902: Székesfehérvár, FEKETE 1959).

Platanthera bifolia (L.) Rchb.: 8777.1 - Pákozd: Kányás; Lovasberény: Vaskapu-h.; 8777.2 Sukoró: Meleg-h.; Lovasberény: Hajagos; Nadap: Farkas-gödör; (LENDVAI et al. 2014).

Podospermum canum C. A. Mey.: 8677.4 - Lovasberény: Kender-tói-dűlő; 8777.2 - Pázmánd: Cseplek-h; 8777.3 - Pákozd: Ősi-h.; 8777.4 - Sukoró: Laposi; (FEKETE 1959, UdVARdY \& BÉNYEI-HIMMER 1999).

Podospermum purpureum (L.) W. D. J. Koch \& Ziz: 8777.1 - Lovasberény: Lászlóházinyiladék; Vaskapu-h.; 8777.3 - Pákozd: Kanca-h.; Világos; Herb. Andreánszky G., 1937, Melegh.; (LENDVAI et al. 2014).

Polygala major Jacq.: 8777.2 - Nadap: Csúcsos-h. alja; Cseket-h. (N 47,2651021 E $18,6435764^{\circ}$ ). félszárazgyepben.

Polygonum bellardii All.: 8777.3 - Pákozd: Telkes-mező; Karácsony-h., Vízmű-d.; Bella-v., Zsellér-mező (N 47,22774833 E 18,52630833); 8777.4 - Nadap: Bence-h., kőbánya feletti degradált gyep.

Potentilla supina L.: 8776.4 - Székesfehérvár: Pátkai-víztározó partján, betonrézsűn; Pákozd: Hajdú-temetés, vízállásos ruderáliában (N 47,21656333 E 18,50755167º).

Prunus fruticosa Pall.: 8777.1 - Lovasberény: Széles-hát, Kánya-v.; 8777.2 - Nadap: Csúcsosh.; Bence-h. alja; Pázmánd: Zsidó-h.; 8777.3 - Pákozd: Telkes-mező; Belső-h.; Abajka; Vontató; Hurka-v.; Bogár-halom; Mészeg-h., Honvéd emlékmű alatt; 8777.4 - Pákozd: Lapos-dűlő; Sukoró: Mészeg-h.; Velence: Bence-h. (FAnTA 1902, Boros 1954, FEKETE 1955, TAMÁS \& CSONTOS 2003).

Prunus tenella Batsch: 8777.2 - Nadap: Temető-h.; János-h.; 8777.3 - Pákozd: Külső-h.; Csúcsos-h; Sukoró: Gádé-dűlő; Szérűskert, 8777.4 - Sukoró: Rigó-h.; Káposztás; (Boros 1954, UDVARDY \& BÉNYEI-HIMMER 1999, LENDVAI et al. 2014). A kistáj területén elterjedése a Velence és Sukoró feletti lejtők xerotherm erdőssztyepp élőhely-maradványain koncentrálódik, de egy-ponton nyugaton (pl. Székesfehérvár: Csúcs-hegy "Aranybulladomb") is megjelenik. BARINA (2008) innen közölte, az állományt ültetettnek tartja, vélekedésével a faj hegységen belüli elterjedési mintázata alapján egyetértek.

Pulsatilla grandis Wender.: 8777.3 - Pákozd: Csúcsos-h, bekerített magánterületen, sztyeppréten. FEKETE (1955) még számos előfordulását említi, jelenleg jóval ritkább a hegységben. Herb. Degen Á., 1908, Kápolnásnyék, Csúcs-h. [a nadapi Csúcsos-hegyre vonatkozhat a lelőhelymegjelölés].

Pulsatilla pratensis subsp. nigricans (Störck) Zämelis: 8777.1 - Pátka: Király-berek, Kilicsán; Pákozd: Bodza-v. felett; 8777.2 - Sukoró: Meleg-h.; Nadap: János-h.; Bence-h.; 8777.3 Pákozd: Telkes-mező; Kis-Fecskés-v.; Belső-h.; Pandúr-kő; Hurka-v.; Külső-h.; Csúcsos-h.; Meszegi-felső-dűlő; Mészeg-h.; Sukoró: Gádé-h.; Gádé-dűlő; 8777.4 - Sukoró: Ördög-kő-h.; Velence: Bence-h.; (FAnTA 1902, Boros 1954, BARINA 2008: Szfh.: Csúcsos-hegy, Jancsár).

Ranunculus pedatus Waldst. \& Kit.: 8677.3 - Lovasberény: Izraelita temető, akácosodó gyepben; 8777.3 - Pákozd: Vontató, Ságmajor közelében; Herb. Boros Á., 1940, ... pedis montis Mészeg; Papp J., 1944, Pákozd: Mészáros-legelő; Kiss Lászlóné, 1961, Velence; (FANTA 1902, Boros 1954).

Rapistrum perenne (L.) All.: 8677.3 - Lovasberény: Izraelita temető; 8677.4 - Lovasberény: Tű-h.; Kenderföldi-dűlő; 8776.4 - Székesfehérvár: Csala-puszta; Kis-Malom-h., a Pátkaivíztározótól délre; 8777.1 - Lovasberény: Szűzvári-h; Kazal-h.; a Velencei-hegység peremterületein szórványosan. Herb. Felföldy L., 1993, Pákozd, ad rivi Császár-víz; (BoRos 1954, UDVARDY \& BÉNYEI-HIMMER 1999). 
Reseda inodora Rchb.: 8777.1 - Lovasberény: Kazal-h. fajgazdag löszpusztagyepben; Herb. Boros Á., 1933, in collibus Velence, versus Nadap; Boros Á., 1949, Sukoró: Csúcsos-h.; (Boros 1937, 1954).

Reseda phyteuma L.: 8777.2 - Nadap: Csúcsos-h.; 8777.3 - Pákozd: Meszegi-alsó-dűlő; Mészeg-h.; 8777.4 - Velence: Bence-h.; a hegység déli és keleti peremhegyein. Herb. Boros A., 1940, Pákozd, Mészeg-h.

Rosa agrestis Savi: 8777.3 - Pákozd: Karácsony-h.; 8777.4 - Velence: Bence-h.; (UDVARDY \& BÉNYEI-HIMMER 1999).

Rosa gallica L.: 8777.1 - Pákozd: Angelika-forrás feletti gyepek, Nagy-legelő; 8777.2 Sukoró: Öreg-h.; Nagy-legelő; Meleg-h; Nadap: János-h.; Csúcsos-h.; Pázmánd: Zsidó-h.; 8777.3 - Pákozd: Telkes-mező; 8777.4 - Pákozd: Mészeg-h.-Lapos-dűlő; (Boros 1954, UDVARDY \& BÉNYEI-HIMMER 1999, TAMÁs \& CSONTOS 2003, LENDVAI et al. 2014).

Rosa hungarica A. Kern.: 8777.1 - Pákozd: Nagy-legelő, Angelika-forrás feletti cserjésedő sztyepprétek; 8777.2 - Nadap: Temető-hegy-dűlő; János-h.; Sukoró: Új-h.; Géczi-h.; Kövecses-h.; Sorompó-v.; Meleg-h.; Nagy-legelő; Sor-h.; 8777.3 - Pákozd: Kis-Fecskés; Csikmák-h.; Sár-h., Urasági-Nagy-mező; Pogány-kő; Sukoró: Gádé-dűlő; Gádé-h.; 8777.4 Sukoró: Rigó-h. (N 47,24148 E 18,583385); Csöpögő-v.; Gyapjaszsák; Ördög-kő-h. Herb. Polgár S., 1937, montis Meleghegy pr. Lovasberény; (KERÉNYI-NAGY 2012).

Rosa inodora Fr.: 8777.2 - Pázmánd: Zsidó-hegy, a három kereszt mögötti cserjésben, ritka (N 47,27436167 ${ }^{\circ}$ E 18,66143667º); 8877.3 - Pákozd: Vontató-Sági-hát. (KERÉNYI-NAGY 2012).

Rosa rubiginosa L.: 8777.2 - Pázmánd: Téglaházi-dűlő cserjésedő löszgyepjei; Zsidó-h.; Nadap: Csúcsos-h.; Sukoró: Új-h.; Meleg-h.; Sor-h.; 8777.3 - Pákozd: Tompos-h.; NagyFecskés; Kis-Fecskés; Karácsony-h.; Bella-v.; Sár-h., Urasági-Nagy-mező; Pogány-kő; Csikmák-h.; Belső-h.; Vontató; Csúcsos-h.; Mészeg-h.; Sukoró: Gádé-dűlő; Gádé-h.; 8777.4 Sukoró: Új-h, Olasz-gránitfejtők; (FANTA 1902: Székesfehérvár, UdVARDY \& BÉNYEI-HIMMER 1999, LENDVAI et al. 2014).

Rosa rugosa Thunbg.: 8777.2 - Nadap: János-h., a platóperemen a Halastói-árok felett, cserjésben elvadulva.

Rosa spinosissima L.: 8777.1 - Pákozd: Kányás; 8777.2 - Nadap: Csúcsos-h.; János-h.; Sukoró: Meleg-h; Lyukas-kő; 8777.3 - Pákozd: Meszegi-felső-dűlő; Mészeg-h.; 8777.4 - Velence: Bence-h.; (KERNER 1869: „Meleghegy bei Stuhlweissenburg”, FEKETE 1955, 1959, UdVARDY \& BÉNYEI-HIMMER 1999, BÖLÖNI 2010).

Rubus canescens DC.: 8777.2 - Nadap: Temető-h.; Sukoró: Meleg-h (N 47,25912833 E 18,59100167º); 8777.4 - Sukoró: Csöntör-h.; Körmösök; Velence: Bence-h.; a kelet-velencei egység területén szórványos.

Rubus idaeus L.: 8777.3 - Pákozd: Bella-völgy, a Kalmár büfétől délre, a patakmeder közelében, üde, árnyas erdőben; 8777.4 - Sukoró: Sorompó-v. alján, gyertyános-tölgyesben

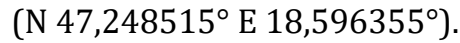

Salsola tragus L. subsp. tragus (syn. Salsola kali subsp. ruthenica (Iljin) Soó): 8777.1 - Pátka: Király-berek; Kilicsán; Lovasberény: Fenyves-v., egykori fluoritbánya; Szöszvári-kaszáló; 8777.2 - Nadap: Magas-dűlő; 8777.3 - Pákozd: Zsellér-legelő; Telkes-mező; Hajdú-temetés; Ősi-h.; Meszegi-alsó-dűlő; a hegység szélein, hegylábi részeken; (FEKETE 1959).

Salvia austriaca Jacq.: 8777.2 - Nadap: Csekés-h.; Pázmánd: Cibulka-patak mente; Cseplek-h.; 8777.3 - Pákozd: Meszegi-alsó-dűlő, Mészeg-h. déli lejtője; 8777.4 - Velence: Csont-rét; Sztyeppréteken, a hegységperemi részeken, igen szórványosan; (KITAIBEL ap. LőKÖs 2001, KERNER 1874a: „am Velenzer See”, Fanta 1902: Székesfehérvár; UDVARDY \& BÉNYEI-HIMMER 1999: Dinnyés).

Saxifraga bulbifera.: 8777.1 - Pátka: Király-berek; Pákozd: Kányás; 8777.2 - Sukoró: Kövecses-h.; 8777.3 - Pákozd: Telkes-mező; Kanca-h.; 8777.4 - Sukoró: Mészeg-h.; Zárt 
sztyeppréteken, igen szórványosan; Herb. Jávorka S., 1927, Csúcsos-h. inter Nadap et Pázmánd.

Saxifraga tridactylites L.: 8777.1 - Pátka: Király-berek; Pákozd: Olasz-v.; 8777.2 - Nadap: Csúcsos-h.; Cseket-h.; 8777.3 - Pákozd: Világos; 8777.4 - Sukoró: Rigó-h.; Herb. Boros Á., 1933, Nadap; (FANTA 1902: Székesfehérvár, "gránittalajról", BARTHA et al. 2015: 8777.1,3).

Scabiosa canescens Waldst. \& Kit.: 8776.4 - Székesfehérvár: Csúcs-h.; Murvás-h.; 8777.1 Pátka: Király-berek; Kilicsán; 8777.2 - Pázmánd: Cseplek-h.; 8777.3 - Székesfehérvár: Csala-puszta, Tompos-h.; Pákozd: Tekes-mező; Ősi-h.; Tompos-h; Kis-Fecskés; Bella-v.; Pandúr-kő; Csúcsos-h. és a Hurka-v. közötti plató; Sukoró: Gádé-dűlő; (FANTA 1902, FEKETE 1955, 1959).

Schoenoplectus litoralis (Schrad.) Palla: A Velencei-tavat lefedő valamennyi CEU-kvadrátban megtalálható a part mentén; néhány lelőhelye: 8777.3 - Pákozd: Tószéli-mező; 8777.4 Sukoró: Lapos-dúlő, Száraz-nádas-bokra; Tószéli-dűlő, Csepegő-víz befolyása; Kis-dűlő part; Velence: Panoráma kemping; Szabadstrand; Gárdony: Félsziget, Déllő-oldala; 8877.1: Gárdony (Agárd): MOHOSZ csónakkikötő, Kis-sarok; 8877.2 Gárdony (Agárd): Park-strand, Csónakkikötő, Hosszú-tisztás; Herb. Felföldy L. et Tóth L., 1972, ad ripam lacus Velencei-tó, pr. pag. Velence; (BARTHA et al. 2015: 8777.4).

Scilla bifolia subsp. spetana (Kereszty) Trávníček: 8777.1 - Pákozd: Hurka-völgy; Külső-erdő (Pákozdvár); 8771.2 - Lovasberény: Antónia-h.; Nadap: Antónia-h.; Bükkhang; Templomhegy, „Mély-út”; Nyír-h.; Farkas-gödör; Sukoró: Meleg-hegy. H: Boros Á. 1922, 1931, Nadap; Degen Á., 1931, Velence; Jávorka S. 1934, Nadap. (lit. Boros 1937, 1954, FeKeTe 1955, 1959, KEVEY et al. 2014).

Scorzonera austriaca Willd.: 8777.1 - Pátka: Király-berek; 8777.2 - Sukoró: Meleg-h.; 8777.4 - Sukoró: Mészeg-h.; a Velencei-hegységben nagyon ritka faj. (FekeTe 1955: Melegh., Pákozd, 1959: Hurka-v., BARTHA et al. 2015: 8777.1).

Scorzonera hispanica L.: 8777.2 - Nadap: Csúcsos-h., cserjésedő sztyeppréten; (BARTHA et al. 2015: 8777.2).

Scorzonera parviflora Jacq.: 8777.3 - Pákozd: Tószéli-mező; Kerektói-lapos szikes rétjein. (KERNER 1872a: „am Velenzer See”, Boros 1954).

Sedum caespitosum (Cav.) DC.: 8777.3 - Pákozd: Ősi-h.; Hajdú-temetés; Telkes-mező; Tompos-h.; Karácsony-h.; 8777.4 - Sukoró: Ördög-kő-h., Fő út, útrézsű;; M7 autópálya útrézsű; Gyapjaszsák dombjai; Új-h., Nagy-legelő; Dögállási-legelő, Vízmű-d.; Herb. Kárpáti Z., 1933, Melegh.; Boros Á., 1933, Melegh.; Pénzes 1933, Melegh.; Kárpáti Z., 1934, Melegh.; Boros Á., 1934, Melegh.; Boros Á., 1940, Pákozd: Mészeg-h.; Boros Á., 1942, Dögállás; Boros Á., 1942, Ördögkö-h.; Károlyi Á., 1953, Melegh.; Csapody V., 1957, Melegh.; (KÁRPÁTI 1934, BoROS 1937, 1954).

Sempervivum matricum Letz: 8777.1 - Pákozd: Hurka-v.; 8777.2 - Sukoró: Sorompó-v.; Rókalyukas-v.; Kövecses-v., Géczi-h.; Meleg-h., Likas-kő; 8777.3 - Pákozd: Hurka-v.; 8777.4 - Velence: Bence-h., nyugati lejtője, Halastói-árok; porló gránitsziklákon, meredek lejtőkön; KERNER $(1870 a)$ saját megfigyelése nyomán hívta fel a figyelmet arra, hogy a Velenceihegység gránitdombjainak jellemző eleme egy kövirózsa faj, amelyet Sempervivum tectorum L. néven publikált, de leírásából is érezhető, hogy bizonytalan volt a taxon megítélése terén. „Auf einer im Jahre 1856 in der Stuhlweissenburger Gegend ausgeführten Exkursion notirte ich gleichfalls ein wildwachsendes "Semperv. tectorum” als haufig auf einem der Quarzitporphyrhügel nördlich von Stuhlweissenburg. ... wahrscheinlich ... S. assimile Schott". Fekete Gábor és a későbbi publikációk már Sempervivum marmoreum Griseb. néven közölték a növény megtalált előfordulásait (FEKETE 1959, UDVARDY \& BÉNYEIHIMMER 1999, BARTHA et al. 2015: 8777.1,3).

Senecio vernalis Waldst. \& Kit.: Néhány adata: 8776.4 - Székesfehérvár: Csúcs-h.; 8777.2 Lovasberény: Meleg-h., útszél; Nadap: Csúcsos-h., szőlőhegyi rész; 8777.3 - Pákozd: 
Suhogó; Karácsony-h.; Csikmák-h.; Csúcsos-hegy-dűlő; Meszegi-alsó-dűlő; 8777.4 - Sukoró: Országút-alatti-dúlő; Velence: Bence-h.; a hegység déli felében és előterében gyakori.

Seseli hippomarathrum Jacq.: 8777.2 - Pázmánd: Zsidó-h.; Cseplek-h.; Sukoró: Meleg-h.; 8777.3 - Pákozd: Tompos-h.; Pogány-kő; a hegység keleti kvarcithegyein gyakori, máshol ritka. (FEKETE 1955, 1959).

Seseli libanotis (L.) W. D. J. Koch: 8777.1 - Lovasberény: Kazal-h.; Nadapi-úti-dúlő; Diós; AlsóCser-h.; 8777.3 - Pákozd: Bella-v.; Urasági-Nagymező alja; (BARTHA et al. 2015: 8777.1).

Seseli osseum Crantz: 8776.4 - Székesfehérvár: Jancsár; 8777.1 - Pátka: Király-berek; 8777.2 - Nadap: János-h.; Bence-h.; Páskom; Pázmánd: Zsidó-h.; 8777.3 - Pákozd: Tompos-h.; Sukoró: Gádé-dűlő; Gádé-h.; 8777.4 - Sukoró: Rigó-h.; Velence: Halastói-árok; a hegység sekély talajú és sziklás gyepjeiben minden részterületen, de csak szórványosan; Herb. Csontos P., 1987, Sukoró; (FEKETE 1955, 1959, UdVARDY \& BÉNYEI-HIMMER 1999, BARTHA et al. 2015: 8777.1).

Seseli pallasii Besser: 8776.4 - Székesfehérvár: Csúcs-h.; Jancsár; Murvás-h.; 8777.1 Székesfehérvár: Kőrakás-h.; Pátka: Király-berek; Kilicsán; Lovasberény: Kazal-h.; 8777.2 Lovasberény: Diós, Cser-h.; Nadap: Csúcsos-h.; Cseket-h.; János-h.; 8777.3 - Pákozd: Ősi-h.; Csikmák-h.; Belső-h.; Bogár-halom; Világos; Sukoró: Gádé-dűlő; Mészeg-h.; Meszegi-felsődűlő; Meszegi-alsó-dűlő; 8777.4 - Sukoró: Rigó-h.; Velence: Bence-h.; különösen a hegylábi részeken és a peremhegyeken gyakori; (FEKETE 1955, 1959, UDVARDY \& BÉNYEI-HIMMER 1999).

Sideritis montana L.: 8776.4 - Székesfehérvár: Csúcs-h.; 8777.2 - Nadap: Cseket-h.; 8777.3 Pákozd: Zsellér-mező-alja; Csikmák-h.; Meszegi-felső-dúlő; 8777.4 - Sukoró: Olaszgránitfejtők; (FANTA 1902: Székesfehérvár, "vetések között", FEKETE 1959, BARTHA et al. 2015: 8777.2).

Silene bupleuroides L.: 8776.4 - Székesfehérvár: Csúcs-h.; 8777.1 - Lovasberény: Kazal-h.; 8777.2 - Nadap: Csúcsos-h.; János-h.; Pázmánd: Zsidó-h.; 8777.3 - Pákozd: Bogár-halmidűlő; Meszegi-felső-dúlő; Mészeg-h.; Sukoró: Csúcsos-h.; 8777.4 - Velence: Bence-h.; Herb. Jávorka S., 1927, Nadap; Boros Á., 1949, Sukoró: Csúcsos-h.; (BoRos 1954, BARTHA et al. 2015: 8777.2, 3).

Silene conica L.: 8777.1 - Pátka: Király-berek; Kilicsán; Lovasberény: Kazal-h.; Alsó-Cser-h.; Nadapi-útra-dúlő; 8777.3 - Pákozd: Suhogó; Tompos-h.; Zsellér-mező-alja; Csikmák-h.; FANTA 1902: Székesfehérvár, "homokos talaj", FEKETE 1959).

Silene coronaria (L.) Clairv.: Erdőkben és cserjésekben, a hegységben közönséges; (FEKETE 1955, 1959, UdVARDY \& BÉNYEI-HIMMER 1999, LENDVAI et al. 2014).

Silene dichotoma Ehrh.: 8777.1 - Pátka: Koldus-telek, 160,8 m-es domb (N 47,26123833 E $18,510225^{\circ}$ ), gránitmurvás, erodált földút szélén.

Silene multiflora (Ehrh.) Pers.: 8777.3 - Pákozd: Bogár-halmi-dűlő; Sós-part; Tószéli-mező; Kerek-tói-lapos; Szúnyog-sziget; 8777.4 - Sukoró: Lapos-dűlő; Laposi; Főleg a hegység déli peremén a Velencei-tó part menti szikes rétjein, mocsarainak szélén, de korábbi herbáriumi (Károlyi Á.) és szakirodalmi (Fekete G.) adatai is vannak a Velencei-hegység kistáj területéről; Herb. Károlyi Á., 1953, Melegh.; (FANTA 1902: Székesfehérvár; FEKETE 1959: Sukoró és Pákozd között, Hurka-v. felé, UdVARDY \& BÉNYEI-HIMMER 1999: Dinnyés).

Silene viscosa (L.) Pers.: 8777.3 - Pákozd: Meszegi-alsó-dűlő; 8777.4 - Sukoró: Ördög-kő-h.; Dögállási-legelő; Herb. Kümmerle J. B., 1917, pr. pag. Dinnyés; Boros Á., 1939, Nagy-sziget, lacus Velencei-tó prope Pákozd.

Sisymbrium altissimum L.: 8777.3 - Pákozd: Csikmák-h.; Mészeg-h.; Pákozd: Csúcsos-h.; 8777.3 - Sukoró: Szérűskert; Degradált sztyeppréteken, útszéleken; Herb. Filarszky N. et Kümmerle J. B., 1904, Nadap: Meleghegy; (FANTA 1902: Székesfehérvár; UdVARDY \& BÉNYEIHIMMER 1999: Meleg-hegy towards the Angelika-spring). 
Sisymbrium loeselii L.: 8777.3 - Pákozd: Külső-h (N 47,24319 E 18,56641833º); Sukoró: Gádé-dűlő; 8777.4 - Sukoró: Páskom-szőlő; Gyomtársulásokban, löszös helyeken.

Smyrnium perfoliatum L.: 8776.4 - Székesfehérvár: Malom-v.; 8777.1 - Lovasberény: Szorosv.; Hajagos; Vaskapu-h.; Nadap: Antónia-h.; Mély-út; Templom-h.; 8777.3 - Pákozd: Belsőh.; Kanca-h., Belső-e.; Hurka-v.; Korábbi adatai csak hegység keleti részéből, a tágabban értelmezett Lovasberényi-erdő térségéből származtak, de szórványosan a nyugat-velencei egység keleti erdős részein is megjelenik; Herb. Boros Á., 1922, Kirchenberg - Cserh.; (Bonos 1937, 1954, FEKETE 1955, 1959, UdVARDY \& BÉNYEI-HIMMER 1999, KEVEY et al. 2014).

Sonchus palustris L.: 8776.4 - Székesfehérvár (Csala): Telkesek, magassásosban; 8777.1 Lovasberény: Szöszvári-kaszáló, Halastó szélén, nádasban; (FANTA 1902: Székesfehérvár, "mocsáros rétek").

Sorbus danubialis (Jáv.) Prodan: 8777.2 - Sukoró: Meleg-h., Likas-kő gerinc északi lejtőjén; 8777.3 - Pákozd: Hurka-völgy, meredekek, északnyugati kitettségű gránitsziklás lejtőjén; mindkét ponton kicsi állomány, néhány termő fa; Korábbi adata csak a Meleg-hegyről volt ismert. Herb., Boros Á., 1934, Sukoró, Melegh.; Kárpáti Z., 1934, Sukoró, Melegh.; (SomLYAY \& SENNIKOV 2015).

Spergularia rubra (L.) J. Presl \& C. Presl: 8777.1 - Pákozd: Angelika-forrás felett, a Nagylegelő nyugati részén; 8777.2 - Nadap: János-h.; 8777.3 - Pákozd: Zsellér-legelő; Telkesmező; Ôsi-h.; Tompos-h.; Bella-v., Zsellér-mező; Pogány-kő; 8777.4 - Sukoró: Ördög-kő-h.; Új-h, Zsellér-nagy-legelő; Velence: Bence-h.; Taposott gyepekben, legelőkön, útszéleken a gránitterületen a belső részeken is elég gyakori; Herb. Boros Á., 1944, Pákozd: Tompos-h.; Boros Á., 1944, Pákozd: Sár-h.

Spiranthes spiralis (L.) Chevall.: 8777.2 - Nadap: Cseket-h.; Pázmánd: Zsidó-h.; Cseplek-h. 8777.3 - Pákozd: Bella-v. felső szakaszán és völgyfője felett platón; a közelmúltban közölt új lelőhelyein túl (TAMÁs \& CSONTOS 2002, ILLYÉs 2006b) újra előkerült a FEKETE (1954, 1955) által publikált helyen (Cseplek-h.) is.

Stachys germanica L.: 8777.2 - Nadap: Új-föld; Temető-h. (N 47,262095 E 18,61373); Cseket-h.; cserjésedő löszös gyepekben.

Sternbergia colchiciflora Waldst. \& Kit.: 8777.1 - Pátka: Kilicsán; Lovasberény: Széles-tető, Kányás-völgy; Bika-v.; Tacsika-h.; Técsi-v.; Pákozd: Hurka-v.-Külső-e.; Pákozdvár; 8777.2 Nadap: Csúcsos-h.; Temető-h.; Nyír-h.; Farkas-gödör.; Új-föld; Pázmánd: Cseplek-h.; Zsidóh.; Sukoró: Sorompó-v.; Kövecses-h.; 8777.3 - Pákozd: Telkes-mező; Hajdú-temetés; Ősi-h.; Belső-e.; Abajka, Ságmajor felett, 210 m-es domb; Vontató; Hurka-v. feletti plató; Polák-h.; Bogár-halom; Meszegi-felső-dűlő; Mészeg-h.; Meszegi-alsó-dűlő; Szúnyog-sziget; 8777.4 Sukoró: Mészeg-h.; Ördög-kő-h.; belterület, Fő út menti árkok, rézsűk. A Velenceihegységben igen gyakori, löszös homokos zárt szárazgyepekben, cserjésekben, xerotherm erdőkben, akácosokban; (BoROs 1954, FEKETE 1955, 1959, BARINA 2008, LENDVAI et al. 2014, MolnÁR et al. 2018).

Stipa dasyphylla (Lindem.) Trautv.: 8777.1 - Pákozd: Bodza-v. feletti sztyepprétek; Angelikaforrás felett, Nagy-legelő; Sor-h.; 8777.2 -; Nadap: Csúcsos-h.; Sukoró: Géczi-h.; Kövecsesh.; Meleg-h. 8777.3 - Pákozd: Hurka-v.; Külső-h.; Herb. Boros Á., Jávorka S., Polgár S., 1937.06.06. (egy napon, közös kiránduláson), Vaskapu-hegy; Bauer N., 2003, Géczi-h.; (Boros 1949, 1954, FEKETE 1955, 1959).

Stipa pennata L.: 8777.1 - Pátka: Kilicsán; Lovasberény: Tacsika-h.; Vaskapu-h., nyiladékon; Pákozd: Bodza-v.; Sor-h.; 8777.2 - Pázmánd: Cseplek-h.; Sukoró: Meleg-h.; Nagy-legelő; 8777.3 - Pátka: Ságmajortól nyugatra, erdei gyepek, nyiladékok; Pákozd: Tompos-h.; Vontató; Hurka-v. feletti plató; Meszegi-felső-dűlő; Sukoró: Gádé-dűlő; Gádé-h.; a hegységben sztyeppréteken sokfelé előfordul; (FEKETE 1955, 1959). 
Stipa pulcherrima K. Koch: 8777.1 - Lovasberény: Kazal-h.; 8777.2 - Nadap: Csúcsos-h.; Pázmánd: Zsidó-h.; a hegység keleti felének sztyepprétjein, kisebb foltokon állományalkotó (N $47,26781667^{\circ}$ E $18,63142667^{\circ}$ ).

Stipa tirsa Steven: 8777.2 - Nadap: Csúcsos-h. délkeleti lábán ( $\mathrm{N}$ 47,27418667 E $18,661955^{\circ}$ ), Magas(-dűlő) cserjésedő félszáraz gyepben.

Succisa pratensis Moench: 8777.3 - Pákozd: Kerek-tói-lapos, kicsi Molinietum folton (N $\left.47,216395^{\circ} \mathrm{E} 18,57274833^{\circ}\right)$.

Taraxacum serotinum (Waldst. \& Kit.) Fisch.: 8677.3 - Lovasberény: Izraelita temető; Jánosh., Tabán; 8677.4 - Lovasberény: Kenderföldi-dűlő ; Tű-h.; 8777.1 - Pátka: Sági-v.; Sági-h.; Lovasberény: Kazal-h.; 8777.2 - Pázmánd: Téglaházi-dűlő; Zsidó-h.; Csekés, szőlőhegyi szárazgyep-foltok; Cseplek-h.; Cibulka-patak menti rézsűk, szárazgyepek; Nadap: Temetőh.; Páskom; Halastói-árok; 8777.3 - Pákozd: Ősi-h.; Telkes-mező; Bogár-halom; Vontató; Világos; Csúcsos-h.; Meszegi-alsó-dűlő; a hegység szélein és peremhegyein löszgyepekben és sztyeppréteken gyakori; Herb. Tauscher Gy., 1868, Nadap; (UDVARDY \& BÉNYEI-HIMMER 1999, MoLnÁR et al. 2018).

Teucrium montanum L.: 8777.1 - Lovasberény: Széles-tető; Pátka: Király-berek; (ILLYÉs \& BÖLÖNI 2007: "szórtan"; BARTHA et al. 2015: 8777.1).

Thelypteris palustris Schott: 8777.2 - Nadap/Sukoró: Halastói-árok, üde cserjésben, forrásos helyen; (FEKETE 1955).

Thrincia nudicaulis (L.) Dostál: 8777.3 - Pákozd: Tompos-h., keleti gerinc, Bella-v., völgyfője felett; a Velencei-tó strandjain, bolygatott parti gyepjeiben sok helyen előfordul, a Velenceihegységben a Tompos-hegy egy bolygatott, üde foltján is előkerült.

Tordylium maximum L.: 8776.4 - Székesfehérvár (Kisfalud): Murvás-h.; 8777.2 - Nadap: Halastói-árok; János-h. (N 47,25132 E 18,61722333º); 8777.3 - Pákozd: Bella-v.; Kulcsárdűlő; Sukoró: Gádé-dűlő; 8777.4 - Sukoró: Rigó-h.; Mészeg-h.; szőlőhelyeken, útszéleken, a hegység déli felén szórványos.

Trifolium diffusum Ehrh.: 8777.3 - Pákozd: Bella-v., Zsellér-mező alja, xerotherm útszéli

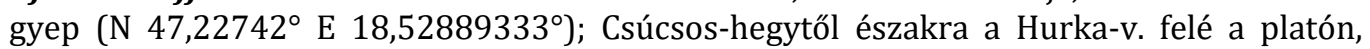
száraz cserjésben. A hegységen kívül, a Dinnyési-fertőn is előkerült: 8877.1 - Gárdony (Dinnyés): Dinnyési-puszta, Festuca pseudovina szikes legelőgyepben.

Trifolium ochroleucon Huds.: 8777.2 - Sukoró: Meleg-h. gerincén, a keleti fő csúcs és nyugati csúcs (Likas-kő felé) közötti nyeregben, tölgyes szélén ( $\mathrm{N} 47,25908667^{\circ} \mathrm{E}$ $18,592395^{\circ}$ ).

Trifolium retusum L.: 8777.1 - Pákozd: Nagy-legelő, Angelika-forrás feletti gyepekben; 8777.2 - Sukoró: Nagy-legelő; Sor-h.; Nadap: János-h., Szintezési-ősjegy feletti dombon; 8777.3 - Pákozd: Ősi-h.; Tompos-h. alja; Suhogó; Karácsony-h.; Mészeg-h.; Sukoró: Gádé-h.; 8777.4 - Sukoró: Ördög-kő-h.; Dögállási-legelő; Gyapjaszsák; Olasz-gránitfejtők; Zsellérnagy-legelő; a Velencei-hegység déli felének legelőin és egykori legelőterületein gyakori; Herb. Boros Á., 1933, Sukoró; Boros Á., 1933, Nadap; (Boros 1937, 1954).

Trifolium striatum L.: 8777.1 - Pákozd: Nagy-legelő, Angelika-forrás feletti gyepekben; 8777.2 - Sukoró: Nagy-legelő; Meleg-h.; Nadap: János-h.; Páskom; Bence-h.; 8777.3 Pákozd: Ősi-h.; Tompos-h.; Nagy-Fecskés; Kis-Fecskés; Sár-h.; Pogány-kő; Meszegi-alsódűlő; Hurka-v.; 8777.4 - Sukoró: Ördög-kő-h.; Gyapjaszsák; a Velencei-hegység déli felének legelőin és egykori legelőterületein általánosan elterjedt és gyakori; (FANTA 1902: Székesfehérvár, "gránittalajról"; Bonos 1937, 1954).

Trigonella procumbens (Besser) Rchb.: 8777.3 - Pákozd: Bogárhalmi-dűlő; Pottya-dűlő; 8777.4 - Sukoró: Csárda-rét; Ördög-kő-h.; útszéleken, mezsgyéken, a velencei-hegység déli peremterületén szórványos. 
Trinia glauca (L.) Dumort.: 8777.1 - Lovasberény: Kazal-h., löszpusztagyepben; 8777.3 Pákozd: Hurka-völgy feletti plató, sekély talajú, cserjésedő sztyeppréten; Herb. Boros Á., 1934, Sukoró: Hurka-v.

Valeriana dioica L.: 8777.3 - Pákozd: Belső-erdő keleti peremén, a Lapos-völgy felső részén, üde égeresben ( $\left.47,23959833^{\circ} \mathrm{E} 18,54998433^{\circ}\right)$.

Valerianella dentata (L.) Pollich: 8777.1 - Lovasberény: Kazal-h.; 8777.2 - Nadap: Csúcsosh.; Pázmánd: Cseplek-h.; sztyeppréteken, szárazgyepekben.

Verbascum speciosum Schrad.: 8777.3 - Pákozd: Ősi-h.; Telkes-mező; hegylábi löszös legelőgyepben.

Veronica dillenii Crantz: 8777.2 - Sukoró: Sorompó-v.; Nadap: Csúcsos-h.; Pázmánd: Cseplekh.; 8777.3 - Pákozd: Tompos-h.; Zsellér-legelő; Sár-h.; Pogány-kő; 8777.2 - Sukoró: Mészeg-h.; Szérűskert; gránit- és kvarcitsziklákon, sekély talajú, murvás felszíneken, pionír gyepekben gyakori; (Boros 1954).

Veronica polita Fr.: 8777.1 - Pátka: Vargahegy; Király-berek; Pákozd: Világos; 8777.2 Nadap: Temető-hegy-dűlő; Csont-rét; 8777.3 - Pákozd: Pottya-dúlő; Meszegi-felső-dűlő; Szúnyog-sziget; 8777.4 - Sukoró: Páskom; településeken, szőlőhegyeken, szántók szélén szórványosan. Herb. Boros Á., 1938, in agris ... pedis montis Varga-hegy pr. Pátka.

Veronica praecox All.: 8777.1 - Pátka: Király-berek; Lovasberény: Tacsika-h.; Kazal-h.; 8777.2 - Pázmánd: Téglaházi-dűlő; 8777.3 - Pákozd: Vontató; Világos; 8777.4 - Sukoró: Rigó-h.; Mészeg-h.; szórványosan, löszgyepekben, löszhatású sztyeppréteken; (BARTHA et al. 2015: 8777.1, 3).

Vicia pannonica subsp. striata (M. Bieb.) Nyman: 8776.4 - Székesfehérvár (Csala): Telkesek; 8777.2 - Sukoró: Géczi-h.; Új-h.; Nadap: Halastói-árok; 8777.3 - Pákozd: Bogár-halom; Csikmák-h.; Vontató; Csúcsos-h. 8777.4 - Sukoró: Meszeg-g.; Szérűskert; Gádé-h.; Gádédűlő; Rigó-h.; Csöntör-h.; Csárda-rét; Ördög-kő-h.; Dögállás; Gyapjaszsák; Köpüs-árok; Körmösök; Páskom; a Velencei-hegység délkeleti részén közönséges, máshol szórványos; (PINKE at al. 2006).

Vinca herbacea Waldst. \& Kit.: 8777.1 - Lovasberény: Szűzvári-h.; Kánya-v., Széles-tető; Bikav.; Tacsika-h.; Vizes-v.; Szoros-v.; Mogyorós-alj; Lászlóházi-erdő; Vaskapu-h.; Pákozd: Pince-d.; Olasz-v.; 8777.2 - Lovasberény: Hársas; Cser-h.; Nadap: Nyír-h.; Templom-h.; Temető-h., Csúcsos-h; Pázmánd: Zsidó-h.; Sukoró: Kövecses-h.; Meleg-h.; Sorompó-v.; Tiborc-v.; Öreg-h. 8777.3 - Pákozd: Abajka; Vontató; Világos; Külső-h.; Mészeg-h.; Meszegialsó-dűlő; 8777.4 - Sukoró: Mészeg-h.; Csöntör-h.; Herb. Boros Á., 1921, Nadap; Jávorka S., 1927, Nadap, Csúcsh.; Boros Á., 1928, Kirchenberg Cser-hegy; Kárpáti Z., 1933, Melegh.; Boros Á., 1934, Hurka-v.; Kárpáti Z., 1934, Melegh.; (KERNER 1873: „auf Quarzitporphyrhügeln am Velenzer See und auf Meleghegy bei Nadáp", FANTA 1902, Boros 1937, FEKETE 1955, 1959, UDVARDY \& BÉNYEI-HIMMER 1999, LENDVAI et al. 2014).

Viola ambigua Waldst. \& Kit.: 8777.1 - Pátka: Abajka; Pákozd: Olasz-v.; Lovasberény: Tacsika-h.; Kazal-h.; 8777.2 - Nadap: Temető-h.; Cseket-h.; Pázmánd: Cseplek-h.; Sukoró: Meleg-h.; 8777.3 - Pákozd: Külső-h.; Csúcsos-h.; 8777.4 - Sukoró: Mészeg-h.; Rigó-h.; Herb. Boros Á., 1921, Melegh.; Jávorka S., 1934, Melegh.; Somlyay L., 2013, Cseplek-h.; Somlyay L., 2013, Cseket-h.

Viola kitaibeliana Schult.: 8776.4 - Székesfehérvár: Csúcs-h.; Jancsár; 8777.1 - Pátka: Abajka; Pákozd: Világos; 8777.2 - Sukoró: Sor-h.; Kövecses-h.; Új-h.; Nadap: János-h.; Vereb: Istenkas; Pázmánd: Téglaházi-dúlő; 8777.3 - Pákozd: Karácsony-h.; Bogár-halom; Világos; Külső-h.; Hurka-v. feletti plató; Sukoró: Csúcsos-h.; 8777.4 - Sukoró: Gyapjaszsák, Géczi-h.; (LENDVAI et al. 2014). 


\section{Köszönetnyilvánítás}

Köszönetet mondok Fekete Gábor (†) tanár úrnak a sok értékes szakmai beszélgetésért, tapasztalatainak megosztásáért, munkám támogatásáért. Köszönöm Lendvai Gábor értékes lektori javaslatait, kiegészítéseit. Köszönettel tartozom Somlyay Lajosnak is, akivel 2010-ben a terület Cotoneaster-fajainak térképezése során, majd 2013-ban az MTM Pákozdi kiállításához kapcsolódóan néhány eredményes, közös terepbejárást tettünk. Néhány alkalommal Bajzáth Judit, Bodorkós Zsolt, Futó János, Hűvös-Récsi Annamária, Kenyeres Zoltán és Tóth Sándor barátaim, valamint családtagjaim is segítették az olykor kirándulásnak álcázott terepi munkámat. Papp Gábor kollégámnak a szakirodalom beszerzésében nyújtott segítségét köszönöm.

\section{Irodalom}

BALOGH M. (1969): A Liparis loeselii (L.) Rich. a velencei tavon (Liparis loeselii (L.) Rich. am Velenceer See). - Botanikai Közlemények 56: 17-19.

BALOGH M. (1971): A lápi vegetáció reliktumai szikes területeken. - Acta Biologica Debrecina 9: 111112.

BALOGH M. (1983): A Velencei-tó nyugati medencéjének uszólápjai és hatásuk a tó vízminőségére. Kandidátusi értekezés tézisei, Budapest, $11 \mathrm{pp}$.

BALOGH M. (2001): A hazai úszólápok florisztikai értékei. - II. Kárpát-medencei Biológia Szimpózium. Budapest, pp. 28-32.

BALOGH M., PATKó Á. \& VÁRI L. (1981): An interesting Liparis presence and its ecological significance on Lake Velencei (Hungary). - Annales Universitatis Scientiarium Budapestinensis de Rolando Eötvös nominatae, Sectio Biologica 22-23: 49-55.

Bartha D., Király G., Schmidt D., Tiborcz V., Barina Z., Csiky J., JakAB G., LeSku B., Schmotzer A., VidéKi R., Vojткó A. \& ZóLYoмi Sz. (szerk.) (2015): Magyarország edényes növényfajainak elterjedési atlasza. Nyugat-Magyarországi Egyetem Kiadó, Sopron, 329 pp.

BARINA Z. (2004): A Dunántúli-középhegység növényföldrajzának főbb jellemzői (Characteristics of the phytogeography Transdanubian Mountains). - Flora Pannonica 2(2): 37-55.

BARINA Z. (2008): Adatok a Dunántúli-középhegység és környéke flórájához (Data on the flora of Hungarian Middle Mountains and neighbouring regions). - Flora Pannonica 6: 3-23.

BARINA Z. (2009): Orobanche alba subsp. major in Hungary. - Studia Botanica Hungarica 40: 5-10.

BAUER N. (2014): A Bakony-vidék szárazgyepjei - Sztyeprétek és sziklagyepek osztályozása és növényföldrajzi karaktere (Dry grasslands of the Bakony Region - Classification and phytogeographical character of dry and rocky grasslands). - A Bakony természettudományi kutatásának eredményei 33: $336 \mathrm{pp}$.

BAUER N., LŐKÖS L. \& PAPP B. (2008): Distribution and habitats of Cardaminopsis petraea (L.) Hiitonen in Hungary. - Studia Botanica Hungarica 39: 113-138.

Borhidi A. \& BALOGH M. (1970): Die Entstehung von dystrophen Schaukelmooren in einem alkalischen (Szik)-See. Ökologisch-zönologische Studien am Velenceer See. - Acta Botanica Hungarica 16(1-2): 13-31.

Boros Á. (1937): Fejér vármegye növénytakarója. - Különlenyomat A magyar városok és vármegyék monográfia XXII. "Fejér vármegye" c. kötetéből, pp. 3-14.

Boros Á. (1954): A Vértes, a Velencei-hegység, a Velencei-tó és környékük növényföldrajza. - Földrajzi Értesítő 3: 280-309.

Boros Á. (1973): Florisztikai jegyzetek 1915-1971. - Magyar Természettudományi Múzeum, Tudománytörténeti Gyüjtemény, mscr.

Boros Á. (1938): Florisztikai közlemények II. - Botanikai Közlemények 35(5-6): 312-320.

Boros Á. (1949): Florisztikai közlemények III. - Borbásia 9(3-5): 28-34.

BöLÖNI J. (1999): Madárbirs fajok (Cotoneaster spp.). - Tilia 7: 193-232. 
BöLÖNI J. (2010): A Velencei-hegység erdeinek jelenlegi képe. - In: MolnÁr Cs., MolnÁr Zs. \& VARGA A. (szerk.), „Hol az a táj szab az életnek teret, Mit az Isten csak jókedvében teremt” Válogatás az első tizenhárom MÉTA-túrafüzetból 2003 - 2009. Vácrátót, pp. 208-215.

CSIKY J. (2006): Adatok Magyarország flórájához és vegetációjához I. - Kitaibelia 10(1) /2005/: 138153.

Csiky J., FARKAS S., KirÁly G., PÁl R., PuRger D. \& Tóth I. Zs. (2005): A Cirsium boujartii (Pill. et Mitterp.) Schultz Bip. újrafelfedezése Magyarországon. - Flora Pannonica 3: 69-77.

DövÉNYI Z. (szerk.) (2010): Magyarország kistájainak katasztere. - MTA Földrajztudományi Kutatóintézet, Budapest, $876 \mathrm{pp}$.

FEKETE G. \& JAKUCS P. (1957): Néhány karsztbokoerdő-faj elterjedési adatainak katalógusa Magyarországról. - Annales Historico-naturales Musei Nationalis Hungarici 8: 181-195.

FeKeTe G. (1954): Chlorocyperus glaber (L.) Palla Magyarországon. - Botanikai Közlemények 45: 253254.

FEKETE G. (1955): Die Vegetation des Velenceer Gebirges. - Annales Historico-Naturales Musei Nationalis Hungarici nov. ser. 7: 343-362.

FEKETE G. (1959): A Velencei-tó, partvidéke és a Velencei-hegység fitocönológiai viszonyai. - Doktori értekezés, Budapest, kézirat, 33 pp. + 16 tab.

FEKETE G. (2010): A Velencei-hegység és környékének vegetációja egykor és ma. - In: MolNÁR Cs., Molnár Zs. \& VARGA A. (szerk.), „Hol az a táj szab az életnek teret, Mit az Isten csak jókedvében teremt" Válogatás az első tizenhárom MÉTA-túrafüzetből 2003 - 2009. Vácrátót, pp. 204-207.

Gомвосz E. (1945): Diaria itinerum Pauli Kitaibelii I-II. - Budapest, 973 pp.

Gyalog L. \& HoRvÁth I. (2004): A Velencei-hegység és a Balatonfö földtana. Geology of the Velence Hills and the Balatonfö. - Magyar Állami Földtani Intézet, Budapest, 316 pp.

Horváth F., DobolyI Z. K., MORSChHAUSER T., LŐKös L., KARAS L. \& SZERDAHELYI T. (1995): FLÓRA adatbázis 1.2. Taxonlista és attribútum-állomány. - Vácrátót, 267 pp.

ILLYÉs E. \& BöLÖNI J. (szerk.) (2007): Lejtősztyepek, löszgyepek és erdőssztyeprétek Magyarországon. Budapest, 236 pp.

ILLYÉs Z. (2006): A Liparis loeselii hazai elterjedése és érzékeny környezetváltást jelző Velencei-tavi élőhelyének vegetációtérképe. - Tájökológiai Lapok 4: 11-32.

ILlYÉs Z. \& TóTH E. (2006): Új őszi füzértekercs (Spiranthes spiralis (L.) Chevall) előfordulás a Velenceihegységben. - Kitaibelia 10(1): 200.

JáVORKA S. (1940): Növényelterjedési határok a Dunántúlon. - Mathematikai és Természettudományi Értesítő 59: 967-997.

KÁRPÁTI Z. (1934): Két érdekes növény a velencei Meleghegyen. - Botanikai Közlemények 31: 43.

KÁRPÁTI Z. (1960): Die Pflanzengeographische Gliederung Transdanubiens. - Acta Botanica Hungarica 6(1-2): 45-53.

KeRESZTY Z. (1993): The distribution of the genus Scilla in Hungary. - Studia botanica hungarica 24: 5175.

KeRESZTY Z., SZILÁGyi L. \& Borhidi A. (1986): Biosystematic studies of the Scilla bifolia complex in Hungary. - Symbolae Botanicae Upsalienses 27(2): 107-112.

KERÉNYI-NAGY V. (2012): Ritka rózsafajok és -hibridek. Rosa spp. - In: BARTHA D. (szerk.), Magyarország ritka fa-és cserjefajainak atlasza. Kossuth Kiadó, Budapest, pp. 207-225.

KERNER A. (1867-1879): Die Vegetationverhältnisse des mittleren und östlichen Ungarns und angrenzenden Siebenbürgens I-CII. - Oesterreichische Botanische Zeitschrift 17-28. Bd.

KERNER A. (1867): Die Vegetationverhältnisse des mittleren und östlichen Ungarns und angrenzenden Siebenbürgens. II. - Oesterreichische Botanische Zeitschrift 17: 215-226.

KERNER A. (1868): Die Vegetationverhältnisse des mittleren und östlichen Ungarns und angrenzenden Siebenbürgens. XV. - Oesterreichische Botanische Zeitschrift 18: 278-285.

KERNER A. (1869): Die Vegetationverhältnisse des mittleren und östlichen Ungarns und angrenzenden Siebenbürgens. XXVI. - Oesterreichische Botanische Zeitschrift 19: 232-236.

KERNER A. (1870a): Die Vegetationverhältnisse des mittleren und östlichen Ungarns und angrenzenden Siebenbürgens. XXXI. - Oesterreichische Botanische Zeitschrift 20: 67-72.

KERNER A. (1870b): Die Vegetationverhältnisse des mittleren und östlichen Ungarns und angrenzenden Siebenbürgens. XXXII. - Oesterreichische Botanische Zeitschrift 20: 103-108.

KERNER A. (1871a): Die Vegetationverhältnisse des mittleren und östlichen Ungarns und angrenzenden Siebenbürgens. XLIII. - Oesterreichische Botanische Zeitschrift 21: 136-142. 
KERNER A. (1871b): Die Vegetationverhältnisse des mittleren und östlichen Ungarns und angrenzenden Siebenbürgens. XLV. - Oesterreichische Botanische Zeitschrift 21: 201-203.

KERNER A. (1872a): Die Vegetationverhältnisse des mittleren und östlichen Ungarns und angrenzenden Siebenbürgens. LII. - Oesterreichische Botanische Zeitschrift 22: 189-193.

KERNER A. (1872b): Die Vegetationverhältnisse des mittleren und östlichen Ungarns und angrenzenden Siebenbürgens. LVI. - Oesterreichische Botanische Zeitschrift 22: 382-390.

KERNER A. (1873): Die Vegetationverhältnisse des mittleren und östlichen Ungarns und angrenzenden Siebenbürgens. LVII. - Oesterreichische Botanische Zeitschrift 23: 16-21.

KERNER A. (1874a): Die Vegetationverhältnisse des mittleren und östlichen Ungarns und angrenzenden Siebenbürgens. LXX. - Oesterreichische Botanische Zeitschrift 24: 149-152.

KERNER A. (1874b): Die Vegetationverhältnisse des mittleren und östlichen Ungarns und angrenzenden Siebenbürgens. LXXIV. - Oesterreichische Botanische Zeitschrift 24: 380-385.

KERNER A. (1875): Die Vegetationverhältnisse des mittleren und östlichen Ungarns und angrenzenden Siebenbürgens. LXXV. - Oesterreichische Botanische Zeitschrift 25: 11-18.

KERNER A. (1877): Die Vegetationverhältnisse des mittleren und östlichen Ungarns und angrenzenden Siebenbürgens. XCV. - Oesterreichische Botanische Zeitschrift 27: 335-339.

KEVEY B. (2015): Adatok Magyarország flórájának és vegetációjának ismeretéhez X. - Botanikai Közlemények 102(1-2): 39-60.

Kevey B., Lendvai G. \& Simon Gy. (2014): A Velencei-hegység gyertyános-tölgyesei (Corydali cavaeCarpinetum Kevey 2008). - Kanitzia 21: 219-244.

Lendvai G., Kevey B. \& HorvÁth A. (2014): A Velencei-hegység tatárjuharos tölgyesei (Aceri tatariciQuercetum pubescentis-roboris Zólyomi 1957). - Botanikai Közlemények 101(1-2): 189-226.

LőKös L. (ed.) (2001): Diaria itinerum Pauli Kitaibelii III. 1805-1817. - Hungarian Natural History Museum, Budapest, $460 \mathrm{pp}$.

MÁTHÉ I. (1940): Magyarország növényzetének flóraelemei. - Acta Geobotanica Hungarica 3: 117-147.

MÁTHÉ I. (1941): Magyarország növényzetének flóraelemei II. - Acta Geobotanica Hungarica 4: 84-108.

MEUSEL H., JÄGER E. \& WEINERT E. (1965): Vergleichende Chorologie der zentraleuropäischen Flora. Band I. Karten. - Gustav Fischer Verlag, Jena, pp. 1-258.

MeUSEL H., JäGER E. \& WEINERT E. (1978): Vergleichende Chorologie der zentraleuropäischen Flora. Band II. Karten. - Gustav Fischer Verlag, Jena, pp. 259-421.

MEUSEL H. \& JäGER E. (1992): Vergleichende Chorologie der zentraleuropäischen Flora. Band III. Karten, Literatur, Register. - Gustav Fischer Verlag, Jena, pp. 422-688.

MÉSZÁRos A., SUlYoK J., VIDÉKI R. \& MolnáR V. A. (2011): Vöth-nőszőfú Epipactis voethii Robatsch 1993. In: Molnár V. A. (szerk.), Magyarország orchideáinak atlasza. Kossuth Kiadó, Budapest, pp. 231232.

Molnár Cs., Molnár Zs., Barina Z., Bauer N., Biró M., Bodonczi L., Bölöni J., Csathó A. I., Csiky J., DeÁK J. Á., Fekete G., Horváth A., Juhász M., Kállayné Szerényi J., Király G., Magos G., Máté A., Mesterházy A., Molnár A., Nagy J., Óvári M., Purger D., Sramkó G., SzénÁs V., Szmorad F., Tóth T. \& Virók V. (2008): Vegetation-based landscape-regions of Hungary. - Acta Botanica Hungarica 50 (Suppl.): 47-58.

Molnár Cs., Haszonits Gy., Malatinszky Á., Kovács G. K., Kovács G., NaGy T., Molnár V. A. \& TakÁcs A. (2017): Pótlások Magyarország edényes növényfajainak elterjedési atlaszához III. - Kitaibelia 22(1): 122-146.

MolnÁR V. A. (2011a): Agár sisakoskosbor Anacamptis morio (L.) Bateman, Pridgeon \& Chaes 1997. In: Molnár V. A. (szerk.), Magyarország orchideáinak atlasza. Kossuth Kiadó, Budapest, pp. 395398.

MolnÁR V. A. (2011b): Kislevelű nőszőfü Epipactis microphylla (Ehrhardt) Swartz 1800. - In: MoLNÁR V. A. (szerk.), Magyarország orchideáinak atlasza. Kossuth Kiadó, Budapest, pp. 214-215.

MolnÁr V. A. (2011c): Tornyos sisakoskosbor Anacamptis pyramidalis (L.) L.C.M. Richard 1817. - In: Molnár V. A. (szerk.), Magyarország orchideáinak atlasza. Kossuth Kiadó, Budapest, pp. 391-392.

Molnár V. A., Mészáros A., CSAThó A. I., Balogh G., TaKács A., LöKi V., Lovas-Kis Á., TöKölyi J., Somlyay L. \& BAUER N. (2018): Distribution and reproduction success of the rare, dry grassland specialist Sternbergia colchiciflora (Amaryllidaceae) in Pannonian graveyards. - Tuexenia 38: 371-384.

Molnár V. A., Molnár A., VidéKi R. \& PFEIfFer N. (2000): Néhány adat Magyarország flórájának ismeretéhez. - Kitaibelia 5(2): 297-303.

NiKLFELD H. (1971): Bericht über die Kartierung der Flora Mitteleuropas. - Taxon 20: 545-571. 
Pinke Gy., PÁl R., Mesterházy A., Király G., Szendrődi V., Schmidt D., Ughy P. \& Schmidmajer Á. (2006): Adatok a Dunántúli-középhegység és a Nyugat-Magyarországi peremvidék gyomflórájának ismeretéhez II. - Kitaibelia 10(1) /2005/: 154-185.

Pócs T. (1981): Növényföldrajz. - In: HoRToBÁGYI T. \& Simon T. (szerk.), Növényföldrajz, társulástan és ökológia. Tankönyvkiadó, Budapest, pp. 27-166.

QGIS Development Team (2016): QGIS Geographic Information System. - OpenSource Geospatial Foundation Project, http://qgis.osgeo.org

RiEziNG N. (2002): Adatok a Dunántúl északi részének flórájához. - Kitaibelia 7(2): 163-167.

SADLER J. (1817): Iter Fürediense. - Magyar Természettudományi Múzeum, Tudománytörténeti Gyüjtemény, Budapest, kézirat, $16 \mathrm{pp}$.

SomLYAY L. (2005): A Budai-hegység florisztikai növényföldrajzának fő vonásai. - Kitaibelia 14(1): 3568.

Somlyay L. \& SEnNikov A. (2015): Atlas Florae Europaeae notes 25. Taxonomic circumscription and nomenclature of Sorbus danubialis (Rosaceae). - Nordic Journal of Botany 34(1):75-86.

TAmás J. \& Csontos P. (2002): Őszi füzértekercs (Spiranthes spiralis (L.) Chevall) a Pázmándi-sziklákon. Botanikai Közlemények 89(1-2): 183-186.

TARSOLY P. (2015): Gránitbarlangok bejárati környezetének lichenológiai, briológiai és pterydológiai vizsgálata a Velencei-hegységben (Lichenological, bryological and pteridological investigation of granite cave entrances in the Velence hills). - Karsztfejlődés 20: 283-292.

TRÁvNíčEK B., DuCHoslav M., ŠARHANOVÁ P. \& ŠAFÁŘovÁ L. (2009): Squills (Scilla s.lat., Hyacinthaceae) in the flora of the Czech Republic, with taxonomical notes on Central-European squill populations. - Acta Musei Moraviae, Scientiae biologicae (Brno) 94: 157-205.

UdVARDY L. \& BÉNYEI-HIMMER M. (1999): Data for flora of the surroundings of Velence Mountains and Lake Velencei. - Publ. Univ. Horticulturae Industriaeque Alimentariae 59: 145-160.

ZólYomi B. (1942): A középdunai flóraválasztó és a dolomitjelenség. (Die Mitteldonau-Florenscheide und das Dolomitphäenomen) - Botanikai Közlemények 39: 209-231.

\section{Világháló hivatkozások}

Euro+Med (2006-): Euro+Med PlantBase - the information resource for Euro-Mediterranean plant diversity. Published on the Internet http://ww2.bgbm.org/EuroPlusMed/ [Hozzáférés 2019.01.01]

The Plant List (2013). Version 1.1. Published on the Internet; http://www.theplantlist.org/ (Hozzáférés 2019.02.15).

Beérkezett / received: 2019. 03.10. • Elfogadva / accepted: 2019. 04. 23. 